\title{
A 125-year record of climate and chemistry variability at the Pine Island Glacier ice divide, Antarctica
}

\author{
Franciele Schwanck $^{1}$, Jefferson C. Simões ${ }^{1}$, Michael Handley ${ }^{2}$, Paul A. Mayewski ${ }^{2}$, Jeffrey D. Auger ${ }^{2}$, \\ Ronaldo T. Bernardo ${ }^{1}$, and Francisco E. Aquino ${ }^{1}$ \\ ${ }^{1}$ Centro Polar e Climático, Universidade Federal do Rio Grande do Sul (UFRGS), Porto Alegre, 91540-000, Brazil \\ ${ }^{2}$ Climate Change Institute, University of Maine, Orono, ME 04469, USA \\ Correspondence to: Franciele Schwanck (franschwanck@gmail.com)
}

Received: 19 October 2016 - Discussion started: 7 November 2016

Revised: 18 May 2017 - Accepted: 23 May 2017 - Published: 4 July 2017

\begin{abstract}
The Mount Johns (MJ) ice core $\left(79^{\circ} 55^{\prime} \mathrm{S}\right.$; $94^{\circ} 23^{\prime} \mathrm{W}$ ) was drilled near the Pine Island Glacier ice divide on the West Antarctic Ice Sheet during the 2008-2009 austral summer, to a depth of $92.26 \mathrm{~m}$. The upper $45 \mathrm{~m}$ of the record covers approximately 125 years (1883-2008), showing marked seasonal variability. Trace element concentrations in 2137 samples were determined using inductively coupled plasma mass spectrometry. In this study, we reconstruct mineral dust and sea salt aerosol transport and investigate the influence of climate variables on the elemental concentrations at the MJ site. The ice core record reflects changes in emissions as well as atmospheric circulation and transport processes. Our trajectory analysis shows distinct seasonality, with strong westerly transport in the winter months and secondary northeasterly transport in the summer. During summer months, the trajectories present slow-moving (short) transport and are more locally influenced than in other seasons. Finally, our reanalysis correlations with trace element suggest that marine-derived trace element concentrations are strongly influenced by sea ice concentration and sea surface temperature anomalies. The results show that seasonal elemental concentration maxima in sea salt elements correlate well with the sea ice concentration winter maxima in the west Amundsen and Ross seas. Lastly, we observed an increased concentration of marine aerosols when sea surface temperature decreased.
\end{abstract}

\section{Introduction}

The West Antarctic Ice Sheet (WAIS) is more susceptible to marine influences than the East Antarctica Ice Sheet (EAIS). The lower average elevation of the WAIS compared to the EAIS, 1100 and $3000 \mathrm{~m}$, respectively (Bedmap 2 project data; Fretwell et al., 2013), facilitates the advection of air masses toward the interior of the continent, thereby directly contributing to the ice sheet's surface mass balance through precipitation (Nicolas and Bromwich, 2011). During recent decades, rapid changes have occurred in the WAIS sector, including flow velocity acceleration, retraction of ice streams, and mass loss (Pritchard et al., 2012). These changes influence the global climate through their contributions to sea level rise (Pritchard et al., 2009; Shepherd et al., 2012) and deep-ocean circulations (Holland and Kwok, 2012). The WAIS contains sufficient water to raise the global sea level by over $3 \mathrm{~m}$ (Bamber et al., 2009; Fretwell et al., 2013).

Major and minor impurities in polar ice originate from sources such as oceans, landmasses, volcanism, biogenic activity, biomass burning, and anthropogenic inputs (Legrand and Mayewski, 1997; Planchon et al., 2002; Vallelonga et al., 2004; Weller et al., 2008; Dixon et al., 2013; Schwanck et al., 2016). These impurities are transported over long distances to the polar regions through the troposphere (Petit and Delmonte, 2009) and stratosphere, e. g. volcanic emissions (Krinner et al., 2010). Sea salt and mineral dust can be used to reconstruct climate conditions as well as atmospheric transport patterns (Albani et al., 2012; Chewings et al., 2014). These chemical elements are strongly influenced by the climate conditions in the source region, and the depositional record provides important information about cyclone 


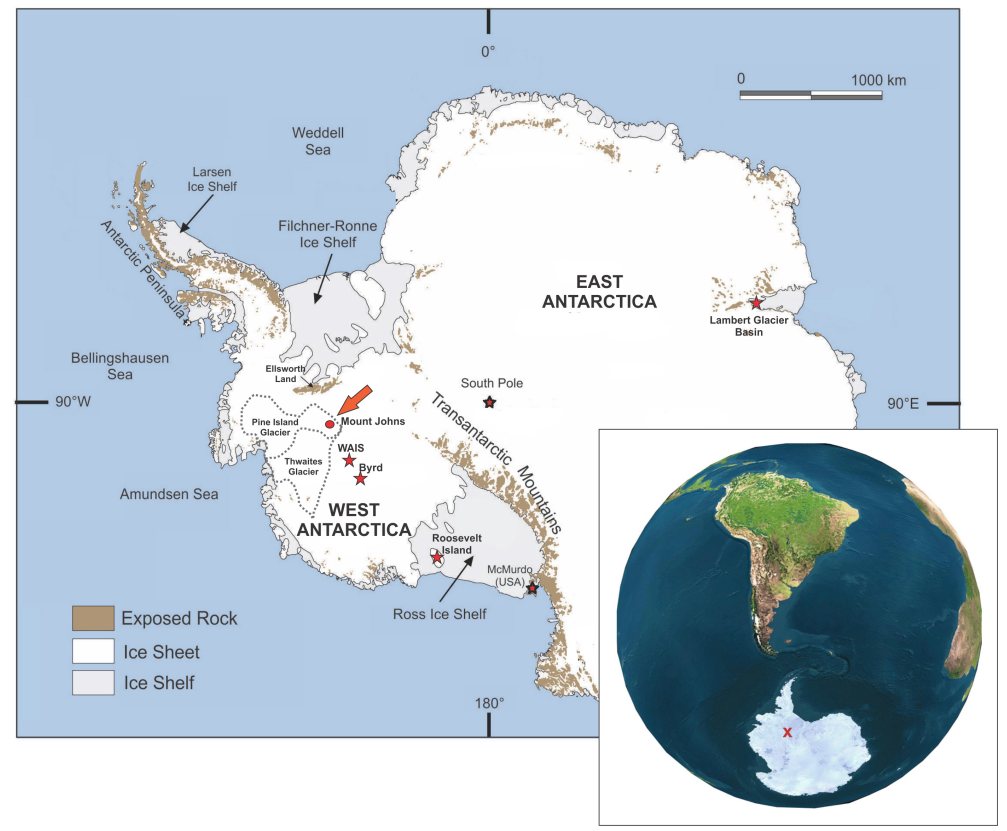

Figure 1. Map of Antarctica showing the site of the MJ ice core site (red arrow) and locations of sites discussed in the text (figure adapted from the U.S. Geological Survey, http://lima.usgs.gov/).

activity, wind intensity (Koffman et al., 2014a), sea ice conditions (Criscitiello et al., 2014), and aridity and vegetation cover (McConnell et al., 2007).

Marine aerosol concentrations are strongly linked to cyclone frequency and intensity that provides high wind speeds over the ocean surface, with the aerosols deposited along the storm track (Fischer et al., 2004). Another primary source of trace elements is mineral dust. It is transported from arid continental regions such as Australia (Revel-Rolland et al., 2006; Li et al., 2008), South America (Delmonte et al., 2010; Li et al., 2010), and probably New Zealand (Neff and Bertler, $2015)$ to the Antarctic. Once entrained into the atmosphere, small grains $(0.1-5 \mu \mathrm{m})$ can be transported over long distances (Gaiero et al., 2007; Mahowald et al., 2014) through advection before they are deposited on the Antarctic snow surface (Prospero et al., 2002; Delmonte et al., 2013).

Here, we present a 125-year record of 11 trace elements (Al, Ba, $\mathrm{Ca}, \mathrm{Fe}, \mathrm{K}, \mathrm{Mg}, \mathrm{Mn}, \mathrm{Na}, \mathrm{S}, \mathrm{Sr}$, and $\mathrm{Ti}$ ) from the Mount Johns (MJ) ice core in the WAIS. We focus on the influence of atmospheric circulation, surface temperature, and sea ice concentration on the transportation of mineral dust and sea salt aerosol to the MJ site. Correlations were made between trace element concentrations and the European Centre for Medium Range Weather Forecasts (ECMWF) Reanalysis Interim (ERA-Interim; Dee et al., 2011) climate variables. Modeled air mass trajectories were also employed to explore atmospheric transport, independent of deposition processes, from 1979 to 2008 .

\section{Methods}

\subsection{Site description and core collection}

Presently, Pine Island Glacier (PIG) is responsible for $20 \%$ of the total ice discharge from the WAIS (Rignot et al., 2008). Accelerated thinning observed since the 1980s is directly linked to enhance sub-ice-shelf melting, which is induced by the recent alteration of Circumpolar Deep Water (Pritchard et al., 2012; Steig et al., 2012; Favier et al., 2014). Sea level pressure and geopotential height anomalies, associated with increased strength of the circumpolar westerlies (Steig et al., 2012), favor reduced sea ice extent in the Amundsen and Bellingshausen seas (Schneider et al., 2011) and the advection of warm air onto the continent (Steig et al., 2009; Ding et al., 2011). In this context, both atmospheric and oceanic variability are important for determining the response of the WAIS over long timescales.

In this study, we use an ice core drilled at the nunatak Mount Johns and near the Pine Island Glacier ice divide (Fig. 1) to reconstruct mineral dust and marine aerosol transport and the influence of climate variables on the elemental concentrations. The MJ ice core $\left(79^{\circ} 55^{\prime} 28^{\prime \prime} \mathrm{S}, 9^{\circ} 23^{\prime} 18^{\prime \prime} \mathrm{W}\right.$, and $91.20 \mathrm{~m}$ depth) was recovered in the austral summer of 2008/2009. The ice thickness at the ice core site reaches $2115 \mathrm{~m}$ (determined from the Bedmap 2 project data; Fretwell et al., 2013). The average accumulation rate for the period is $0.21 \mathrm{mw}^{2}$.e year ${ }^{-1}$ (based on calculated field measurements of snow and ice density), and the mean surface 
temperature (measured at a depth of $12 \mathrm{~m}$ ) is $-33^{\circ} \mathrm{C}$, measured using a calibrated platinum probe.

Drilling was performed using the Fast Electromechanical Lightweight Ice Coring System (FELICS) (Ginot et al., 2002). The MJ core ( $8.5 \mathrm{~cm}$ diameter) was cut into sections of approximately $1 \mathrm{~m}$ in length, packed in polyethylene bags and then stored in high-density Styrofoam boxes and transported by air to Punta Arenas, Chile. Then, it was sent frozen to the Climate Change Institute (CCI) at the University of Maine, USA, where it was subsampled and analyzed using inductively coupled plasma sector field mass spectrometry (ICP-SFMS).

\subsection{Laboratory analyses}

Decontamination of the MJ ice core was carried out in a certified cold room ISO 5 with temperature below $-20^{\circ} \mathrm{C}$. Prior to melting, core ends and breaks were manually scraped using a clean ceramic knife to reduce potential contamination from drilling or other sources (procedure performed according Tao et al. (2001) and described in Schwanck et al. (2016)). The core was melted using a continuous ice core melter system developed by CCI researchers (details in Osterberg et al., 2006). This system uses fraction collectors to gather discrete, high-resolution, continuous, and coregistered meltwater samples. Our samples were collected into acid-cleaned (Optima $\mathrm{HNO}_{3}$ ) low-density polyethylene (LDPE) vials and acidified to $1 \%$ with double-distilled $\mathrm{HNO}_{3}$. All sample handling was conducted in an ISO 5 clean room under a laminar flow high-efficiency particle air (HEPA) bench. The samples were allowed to react with the acid (at room temperature) at least 1 month before analysis. This process is important to guarantee a complete dissolution of particulate and non-soluble elemental fractions (Rhodes et al., 2011; Koffman et al., 2014b).

Trace element concentrations in 2137 discrete samples, corresponding to the upper $45 \mathrm{~m}$ of the MJ ice core, were determined using the CCI Thermo Scientific ELEMENT 2 ICPSFMS coupled to an ESI model SC-4 autosampler. Working conditions and measurement parameters are described in Table S1 in the Supplement. The ICP-SFMS is calibrated daily with five standards that bracket the expected sample concentration range. Although there is no certified reference material for trace elements in polar snow and ice, the analyzed samples were certified with water reference material (SLRS4, National Research Council Canada, Ottawa, Canada) to ensure the concentrations were within the certification range, confirming the accuracy of this method (details in Osterberg et al., 2006).

Samples of deionized water, or "blanks", were prepared, treated, and analyzed using the same method applied to snow samples. The method detection limits (MDLs) were defined as 3 times the standard deviation of blank samples (10 blank samples were used). Concentrations below the MDL were replaced with the MDL values, which occurred in a few cases for $\mathrm{Al}, \mathrm{Ba}, \mathrm{Ca}, \mathrm{Fe}, \mathrm{Mn}, \mathrm{Sr}$, and $\mathrm{Ti}$ (less than $1 \%$ ). Blank concentrations and MDLs were either similar to or less than published values using comparable methods and instruments (Table S2).

Water isotope analyses were performed at the Centro Polar e Climatico, Brazil, Isotopes Lab using a Picarro L2130i wavelength-scanned cavity ring-down spectroscopy (WSCRDS) instrument (Picarro Inc., USA). The samples collected at the CCI were sent frozen to Brazil and melted on the day of analysis. Aliquots of water were filled in $2 \mathrm{~mL}$ glass vials and sealed with polytetrafluorethylene/silicone caps. The vials were then placed in a PAL COMBI PAL autosampler (CTC Analytics AG, Switzerland) connected to the Picarro L2130-i for $\delta \mathrm{D}$ and $\delta^{18} \mathrm{O}$. Reproducibility of measurements is typically $0.9 \%$ or $\delta \mathrm{D}$ and $0.2 \%$ for $\delta^{18} \mathrm{O}$.

\subsection{Meteorological data analyses}

To explore possible sources of the observed trace elements in aerosols, air mass backward trajectories were simulated for $1000 \mathrm{~m}$ above ground level over the MJ ice core site. Trajectory simulations were made using the Hybrid Single-Particle Lagrangian Integrated Trajectory (HYSPLIT) model, developed by the NOAA Air Resources Laboratory (Draxler et al., 2010) in conjunction with the global reanalysis data sets from the National Centers for Environmental Prediction (NCEP) and the National Center for Atmospheric Research (NCAR), known as the NCEP/NCAR reanalysis model (NCEP1) (Kalnay et al., 1996; Kistler et al., 2001). Despite limitations prior to the satellite era (1979), the NCEP/NCAR reanalysis model represents a useful tool for understanding the climate of the Southern Hemisphere from 1979 onwards (Bromwich and Fogt, 2004) and has been used with success in Antarctic back-trajectory modeling (e.g., Sinclair et al., 2010; Dixon et al., 2011; Markle et al., 2012).

Five-day (120 h) 3-D back trajectories were created from the MJ site at 00:00 UTC daily from January 1979 to December 2008 (a total of 10655 trajectories). We have tested the effect of model initiation heights at 500,1000, and $1500 \mathrm{~m}$ on our trajectories and confirmed they are spatially consistent. The initial heights of $500 \mathrm{~m}$ are affected by surface topography, which is imperfectly represented in the reanalysis model (Dee et al., 2011). For this reason, we have chosen the $1000 \mathrm{~m}$ level as the initial height condition for our back trajectories. At this altitude, orographic influences are minimized, while the trajectories are sufficiently close to the terrain to be dynamically linked to the surface wind field (Sinclair et al., 2010). The 5-day simulation is an appropriate length of time when considering the maximum lifetime transport (10 days) of small size $(0.1-2.5 \mu \mathrm{m})$ fractions of mineral dust and other aerosols, while transport of large particles $(>2.5 \mu \mathrm{m})$ is likely restricted to the first several days (Albani et al., 2012). Cataldo et al. (2013) measured the size of dust particles in a separate ice core drilled near MJ and 
Table 1. Statistical summary of trace elements concentrations determined in the MJ ice core.

\begin{tabular}{lrrrrrrr}
\hline Elements & Mean & Median & SD & $\begin{array}{r}\text { Average } \\
\text { uncertainty }\end{array}$ & Min & Max & MDL* \\
\hline $\mathrm{Al}\left(\mathrm{ngg}^{-1}\right)$ & 2.64 & 2.46 & 1.65 & 0.03 & 0.30 & 22.77 & 0.30 \\
$\mathrm{Ba}\left(\mathrm{pgg}^{-1}\right)$ & 9.31 & 5.49 & 11.45 & 0.24 & 0.38 & 93.46 & 0.38 \\
$\mathrm{Ca}\left(\mathrm{ngg}^{-1}\right)$ & 3.01 & 1.88 & 3.24 & 0.07 & 0.09 & 21.22 & 0.09 \\
$\mathrm{Fe}\left(\mathrm{ngg}^{-1}\right)$ & 0.62 & 0.41 & 0.68 & 0.01 & 0.05 & 5.58 & 0.05 \\
$\mathrm{~K}\left(\mathrm{ngg}^{-1}\right)$ & 1.78 & 0.94 & 3.39 & 0.07 & 0.06 & 39.54 & 0.06 \\
$\mathrm{Mg}\left(\mathrm{ngg}^{-1}\right)$ & 9.27 & 9.09 & 4.71 & 0.10 & 0.66 & 45.18 & 0.38 \\
$\mathrm{Mn}\left(\mathrm{pgg}^{-1}\right)$ & 28.10 & 11.99 & 61.60 & 1.34 & 0.94 & 783.79 & 0.94 \\
$\mathrm{Na}\left(\mathrm{ngg}^{-1}\right)$ & 21.91 & 12.64 & 33.10 & 0.69 & 0.21 & 381.61 & 0.21 \\
$\mathrm{~S}\left(\mathrm{ngg}^{-1}\right)$ & 10.24 & 9.01 & 6.30 & 0.14 & 0.58 & 62.53 & 0.06 \\
$\mathrm{Sr}\left(\mathrm{pgg}^{-1}\right)$ & 23.21 & 17.74 & 17.85 & 0.38 & 0.74 & 117.94 & 0.74 \\
$\mathrm{Ti}\left(\mathrm{pgg}^{-1}\right)$ & 14.15 & 9.00 & 18.76 & 0.37 & 0.66 & 209.35 & 0.66 \\
\hline
\end{tabular}

* Method detection limit.

found that the mean dust size within the core ranges from 1.2 to $2.4 \mu \mathrm{m}$.

In order to obtain information about airflow patterns at the MJ site, a cluster analysis was applied to a database of individual trajectories (10655 daily trajectories). The HYSPLIT model's cluster analysis algorithm groups trajectories by minimizing the spatial variability between trajectories within some defined number of clusters (Draxler, 1999). For the trajectories presented here, it is determined that five clusters is a sufficient amount to capture seasonal variability during the 1979-2008 period.

Bracegirdle and Marshall (2012) determined that ERAInterim was the most accurate of six reanalysis models over Antarctica when compared against surface and midtropospheric pressure and temperature observations. ERA-Interim was thus utilized to provide annual mean $2 \mathrm{~m}$ air temperature $\left(T_{2} \mathrm{~m}\right)$, sea surface temperature (SST), and sea ice concentration (SIC) from 1979 to 2008. ERA-Interim outputs were obtained from the ECMWF data server (http://apps. ecmwf.int/datasets/) at a resolution of $1.5^{\circ}$. Spatial correlations were performed between $\mathrm{MJ}$ ice core element data and ERA-Interim climate variables.

\section{Results and discussion}

\subsection{Dating of the ice core}

The aerosol records show strong seasonal variations due to seasonality in aerosol sourced and transport efficiency, and these seasonal signals can be used to detect annual layers (e.g., Sigl et al., 2016). A typical annual layer at the MJ site is characterized by a maximum of sea salt aerosol deposition (e.g., $\mathrm{Na}, \mathrm{Sr}$ ) during austral winter and a maximum of marine biogenic aerosol emission (e.g., S) in late austral summer. Manual interpretation of the data was done by multiple individuals to identify the individual layers. The CCI soft- ware package (Kurbatov et al., 2005) was also used to identify matching seasonal peaks from $\mathrm{Ca}, \mathrm{Na}$, and $\mathrm{Sr}$ and the major historical volcanic eruptions. In this study, water isotopes were used to confirm the dating previously performed in Schwanck et al. (2016). The major historical volcanic events during this period - such as Pinatubo (1991), Agung (1963), Santa Maria (1902), and Krakatoa (1883) - are identified by large peaks in $\mathrm{S}$ concentration and are used as absolute time horizons during timescale development (Fig. S1 in Supplement). On the basis of our dating, the upper $45 \mathrm{~m}$ of the MJ ice core covers the period from AD 1883 to 2008. We estimate a maximum dating error of \pm 1 year between the AD 1991 Pinatubo and AD 1963 Agung eruptions, and \pm 2 years between the AD 1963 Agung and AD 1883 Krakatoa eruptions.

\subsection{Glaciochemical records}

Concentrations of 11 trace elements (Al, Ba, Ca, Fe, K, Mg, $\mathrm{Mn}, \mathrm{Na}, \mathrm{S}, \mathrm{Sr}$, and $\mathrm{Ti}$ ) were measured in 2137 discrete ice core samples. Table 1 shows a statistical summary of the trace element concentrations measured from the MJ ice core.

The soil and rock dust contribution for the measured trace elements was given by the crustal enrichment factor $\left(\mathrm{EF}_{\mathrm{c}}\right)$ according to Eq. (1) (Osterberg, 2007):

$\mathrm{EF}_{\mathrm{c}}=\frac{X_{\text {ice }} / \mathrm{Al}_{\text {ice }}}{X_{\text {ref }} / \mathrm{Al}_{\text {ref }}}$,

where $X_{\text {ice }}$ is the trace element concentration in the sample; $\mathrm{Al}_{\text {ice }}$ is the aluminum concentration in the sample; and $X_{\text {ref }}$ and $\mathrm{Al}_{\text {ref }}$ are the trace element and the aluminum concentrations in the reference material, respectively. Aluminum was used as the reference element in this work because it is a good proxy of continental dust (Planchon et al., 2002). The mean elemental concentration used for reference is the av- 

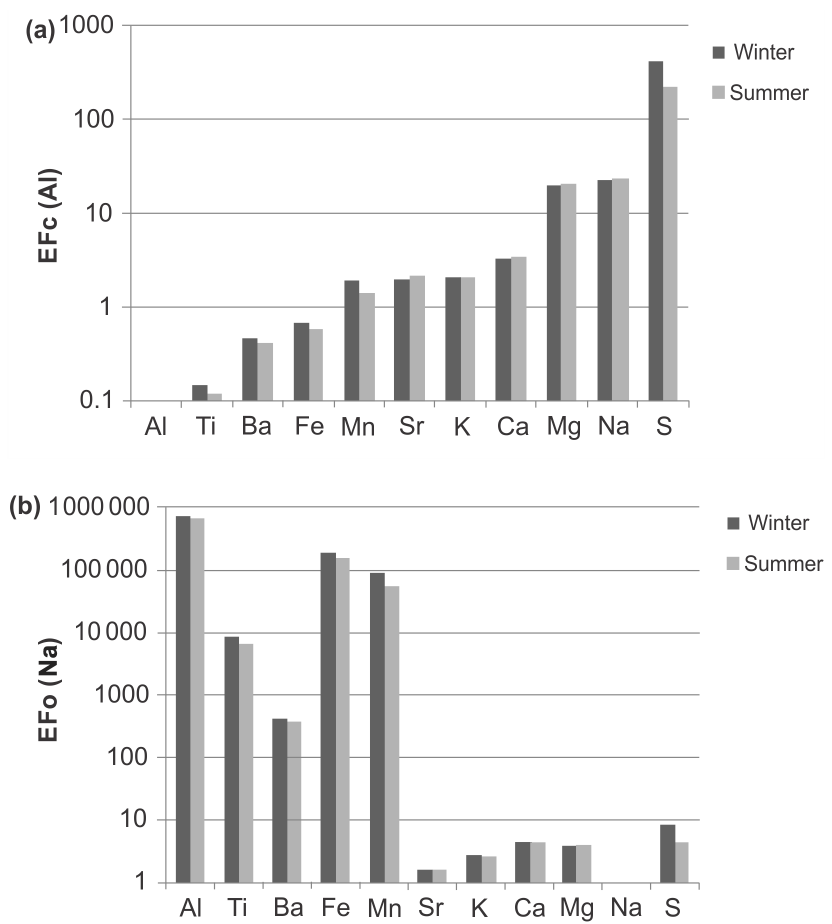

Figure 2. (a) Mean element enrichment factors in reference to Earth's crust (EFc) and (b) oceanic composition (EFo) at the MJ site for austral summer (December-February) and austral winter (JuneAugust).

erage composition of the upper continental crust taken from the literature (Wedepohl, 1995).

Figure 2 shows trace element $\mathrm{EF}_{\mathrm{c}}$ values during the austral summer and winter months in the MJ ice core. Elements with $\mathrm{EF}_{\mathrm{c}}$ lower than 10 are considered to be non-enriched and predominantly have a crustal dust origin (Duce et al., 1975). $\mathrm{EF}_{\mathrm{c}}$ higher than 10 indicates contributions from other sources, such as marine aerosol, volcanism, biogenic activity, or anthropogenic emissions. Marine aerosol contributions were estimated using the oceanic enrichment factor $\left(\mathrm{EF}_{\mathrm{o}}\right)$ according to Eq. (2) (Osterberg, 2007):

$\mathrm{EF}_{\mathrm{o}}=\frac{X_{\text {ice }} / \mathrm{Na}_{\text {ice }}}{X_{\text {ref }} / \mathrm{Na}_{\text {ref }}}$,

where $X_{\text {ice }}$ is the trace element concentration in the sample; $\mathrm{Na}_{\text {ice }}$ is the $\mathrm{Na}$ concentration in the sample; and $X_{\text {ref }}$ and $\mathrm{Na}_{\text {ref }}$ are the trace element and $\mathrm{Na}$ concentration in the reference material, respectively. Sodium is used as the reference element because it is the main sea salt constituent (Weller et al., 2008; Dixon et al., 2013). We used the average composition of ocean water (Lide, 2005) as a reference for the ocean elemental abundances.

Non-sea-salt (nss) sulfur ratios were calculated using Eq. (3) (Palmer et al., 2002; Becagli et al., 2005):

$\mathrm{nssS}=\mathrm{S}-0.084 \times \mathrm{ssNa}$, where $\mathrm{S}$ is the total sulfur concentration on the sample, 0.084 is the mean $\mathrm{S} / \mathrm{Na}$ ratio in seawater (Lide, 2005), and ssNa is the $\mathrm{Na}$ actually derived from sea spray. Since some $\mathrm{Na}$ derives from continental dust, ssNa was calculated using the equation system (4) reported below:

$\operatorname{ssNa}=\mathrm{Na}-\mathrm{nssNa}$,

$\mathrm{nssNa}=\mathrm{nssAl} \times(\mathrm{Na} / \mathrm{Al})_{\text {crust }}$,

$\mathrm{Al}=\mathrm{nssAl}$,

where the mean $\mathrm{Na} / \mathrm{Al}$ ratio is 0.3315 in the crust (Wedepohl, 1995). In this study, we assume that $\mathrm{Al}$ is only of crustal origin (total Al is equal to nssAl). Wagenbach et al. (1998) suggested that the seawater ratio at Antarctic coastal sites is variable because of fractionation processes (formation of frost flowers on fresh sea ice and precipitation of mirabilite at temperatures below $-8.2{ }^{\circ} \mathrm{C}$ ). It can be recognized by obtaining negative nssS concentrations. The Mount Johns record shows a deficit of nssS during the winter in a few years. However, it corresponds to less than $1 \%$ of the samples, and we consider that the sulfur fractionation does not affect the ratio in the MJ area.

The sulfur contribution from marine phytoplankton activity (via atmospheric oxidation of dimethyl sulfide produced by marine phytoplankton during summer months) was estimated from the methanesulfonate (MSA, a specific marker of marine biogenic emissions) concentration (following Udisti et al., 2016). About $30 \%$ of the nssS concentration in the MJ area was considered to be of biogenic origin.

Approximately $10-15 \%$ of the non-sea-salt sulfate/sulfur concentration in the Antarctic atmosphere originates from volcanic activity (Boutron and Paterson, 1986; Hur et al., 2007). We used the Hinkley et al. (1999) element/S ratios to calculate inputs from the global mean volcanic quiescent degassing background for the elements $\mathrm{Mn}$ and S (there are no data available for the other elements). Furthermore, we used the metal / S ratios from the Mount Erebus $\left(77^{\circ} 32^{\prime} \mathrm{S}\right.$, $167^{\circ} 10^{\prime} \mathrm{E}$ ) plume (Zreda-Gostynska et al., 1997) to represent local source contributions for $\mathrm{Al}, \mathrm{Ca}, \mathrm{Fe}, \mathrm{K}, \mathrm{Mn}, \mathrm{Na}, \mathrm{S}$, and Ti. The first step to calculating the volcanic contribution is to remove the oceanic and crustal fraction of elements. We are left with the excess $($ excess $=$ total $-($ oceanic + crustal $))$ elemental concentrations to calculate the local $(3-5 \%)$ and global (10-15\%) volcanic contributions (Table S3).

Only S and Mn show significant input of volcanic emissions, with contributions ranging from 20 to $33 \%$ from global volcanic sources and from 3 to $5 \%$ from regional emissions for mean excess elemental concentrations. The other elements ( $\mathrm{Al}, \mathrm{Ca}, \mathrm{Fe}, \mathrm{K}, \mathrm{Na}$, and $\mathrm{Ti}$ ) presented less than $1 \%$ of volcanic input. Due to a lack of data in the literature, we did not calculate volcanic increments for the elements $\mathrm{Ba}$, $\mathrm{Mg}$, and $\mathrm{Sr}$. 
Table 2. Principal component loadings for the Mount Johns trace elements concentrations (PCA loadings $>0.3$ are shown in bold).

\begin{tabular}{lrrrr}
\hline \multirow{2}{*}{ Element } & \multicolumn{4}{c}{ Component } \\
\cline { 2 - 5 } & 1 & 2 & 3 & 4 \\
\hline $\mathrm{Al}$ & 0.24 & $\mathbf{0 . 5 9}$ & -0.26 & 0.05 \\
$\mathrm{Ba}$ & $\mathbf{0 . 3 6}$ & 0.01 & $\mathbf{0 . 3 0}$ & -0.07 \\
$\mathrm{Ca}$ & 0.22 & -0.18 & 0.24 & $\mathbf{0 . 6 6}$ \\
$\mathrm{Fe}$ & 0.20 & 0.19 & $\mathbf{0 . 5 9}$ & -0.02 \\
$\mathrm{~K}$ & $\mathbf{0 . 3 2}$ & $\mathbf{- 0 . 3 2}$ & 0.06 & -0.17 \\
$\mathrm{Mg}$ & $\mathbf{0 . 3 2}$ & 0.28 & $\mathbf{- 0 . 5 0}$ & 0.17 \\
$\mathrm{Mn}$ & $\mathbf{0 . 3 7}$ & -0.18 & 0.03 & $\mathbf{- 0 . 3 6}$ \\
$\mathrm{Na}$ & $\mathbf{0 . 3 7}$ & $\mathbf{- 0 . 3 4}$ & -0.19 & -0.03 \\
$\mathrm{~S}$ & 0.29 & 0.06 & -0.10 & $\mathbf{- 0 . 4 4}$ \\
$\mathrm{Sr}$ & $\mathbf{0 . 3 4}$ & -0.17 & -0.17 & $\mathbf{0 . 4 0}$ \\
$\mathrm{Ti}$ & 0.21 & $\mathbf{0 . 4 6}$ & $\mathbf{0 . 3 2}$ & 0.03 \\
$\mathrm{Percent}$ of variance & $42.24 \%$ & $13.27 \%$ & $11.16 \%$ & $8.11 \%$ \\
$\mathrm{Cumulative} \mathrm{percent}$ & $42.24 \%$ & $55.51 \%$ & $66.67 \%$ & $74.77 \%$ \\
\hline
\end{tabular}

\subsection{Principal component analysis}

To evaluate the origin and transport of the trace elements determined in the MJ ice core, we applied principal component analysis (PCA) in order to reveal linear relations existing in the chemical data set. For our study, OriginPro 2017 for Windows (OriginLab Corporation, USA) was utilized for the multivariate statistical analysis and for descriptive and correlation analyses.

PCA is widely used to reduce data (Loska and Wiechuya, 2003; Gabrielli et al., 2008) and to extract a small number of latent factors (principal components, PCs) for analyzing relationships among the observed variables (Table S4). The PCA applied to the entire chemical data set resulted in four PCs (Table 2) reporting 42.24, 13.27, 11.16, and $8.11 \%$ of the total variance of 11 trace elements.

All trace elements correlate positively on PC1 with $\mathrm{Ba}, \mathrm{K}$, $\mathrm{Mg}, \mathrm{Mn}, \mathrm{Na}$, and $\mathrm{Sr}$ obtained the highest scores; $\mathrm{PC} 2$ is positively dominated by $\mathrm{Al}, \mathrm{Fe}, \mathrm{Mg}$, and $\mathrm{Ti}$, and with $\mathrm{Ca}, \mathrm{K}$, $\mathrm{Mn}, \mathrm{Na}$, and $\mathrm{Sr}$ negatively correlated. PC3 is positively dominated by $\mathrm{Ba}, \mathrm{Ca}, \mathrm{Fe}$, and $\mathrm{Ti}$, while $\mathrm{Al}$ and $\mathrm{Mg}$ are negatively correlated. Finally, PC4 is positively dominated by $\mathrm{Ca}, \mathrm{Mg}$, and $\mathrm{Sr}$, while $\mathrm{S}$ and $\mathrm{Mn}$ are negatively correlated.

PC1 appears to be an impurity index with each element correlated positively within the PC. When the atmosphere load is high (high impurity content), PC1 shows high values. Conversely, when impurity concentration reaches minimum values, PC1 is low (Fig. 3). PC2 and PC3 seem to be derived from soil dust, as the elements that are positively correlated are the main components of soil and crustal. However, the negatively correlated elements in $\mathrm{PC} 2$ point to marine aerosol deposition. Also, we can say that $\mathrm{PC} 2$ highlights aluminosilicate ( $\mathrm{Al}$ is the most important element), while PC3 highlights the siliciclastic fraction of mineral dust (Fe and Ti). Last, PC4 is related to carbonate content, where $\mathrm{Ca}, \mathrm{Mg}$, and $\mathrm{Sr}$ are major constituents of $\mathrm{CaCO}_{3}$.
Based on the analysis of crustal and marine enrichment factors and PCA, we have classified the concentrations as predominantly crustal for the elements $\mathrm{Al}, \mathrm{Mg}$, and $\mathrm{Ti}$, while $\mathrm{Na}, \mathrm{Sr}$, and $\mathrm{Ca}$ are primarily sea-salt-derived elements. The elements $\mathrm{Ba}, \mathrm{Mn}, \mathrm{Fe}$, and $\mathrm{K}$ appear to be from mixed sources (mineral dust and sea salt aerosol). Furthermore, the $\mathrm{S}$ record has a considerable volcanic and biogenic input and Mn has an additional volcanic input. We acknowledge that Fe may have an additional contribution of biomass burning aerosol (Winton et al., 2016), but due to a lack of data we will not address this issue here. Based on the low values of $\mathrm{EFc}$ and $\mathrm{EFo}$, we presume that the presented concentrations are of natural origin and that possible anthropogenic contributions to these elements would be insignificant in this area.

\subsection{Intraseasonal concentration fluxes variability}

Generally, trace element concentrations from sea salt aerosol observed in coastal and interior West Antarctic ice cores show a clear seasonal signal, with higher concentrations in austral winter and spring months (June-November) and lower concentrations in austral summer months (DecemberFebruary) (Legrand and Mayewski, 1997; Sigl et al., 2016). Impurities from continental dust can peak in both the austral summer (Weller et al., 2008; Tuohy et al., 2015) and winter months (Hur et al., 2007), depending on site location. Dust deposition is mainly influenced by local factors and atmospheric circulation patterns. Additionally, biogenic aerosols (e.g., sulfur) show peaks in summer months due to an increased phytoplankton activity (Weller et al., 2011). We found high concentrations in austral winter and low concentrations in austral summer for most of the elements analyzed, with the exception of sulfur, which presents peaks in the summer due to the biogenic contribution, and of the elements with crustal influence ( $\mathrm{Al}, \mathrm{Ba}, \mathrm{Mg}$, and $\mathrm{Ti})$, which present the highest concentrations in spring and summer.

To investigate whether observed changes in chemistry are related to changes in accumulation rate, we calculated the annual deposition flux for all elements. The flux is calculated by multiplying the concentrations in the ice by the annual water-equivalent accumulation rate. The annual flux for all trace elements is shown in Fig. 4. Both concentration and flux present similar variability (not shown); this indicates that the concentrations are independent of accumulation rate and that the variability exhibited in the record is likely not a function of changes in snow accumulation.

The fluxes are highly variable down the length of the core. In particular, there are three distinct phases in the record: (i) between 1885 and around 1930 fluxes peak for Al, Ba, $\mathrm{Fe}, \mathrm{Mg}, \mathrm{S}$, and Ti; (ii) between approximately 1930 and 1955 minimum fluxes can be observed for the above trace elements; and (iii) between approximately 1955 and 2008 a second increasing trend is observed for $\mathrm{Al}, \mathrm{Ba}, \mathrm{Fe}, \mathrm{Mg}, \mathrm{S}$, and Ti. The ice core record reflects changes in emissions as well as atmospheric circulation and transport processes. The El 


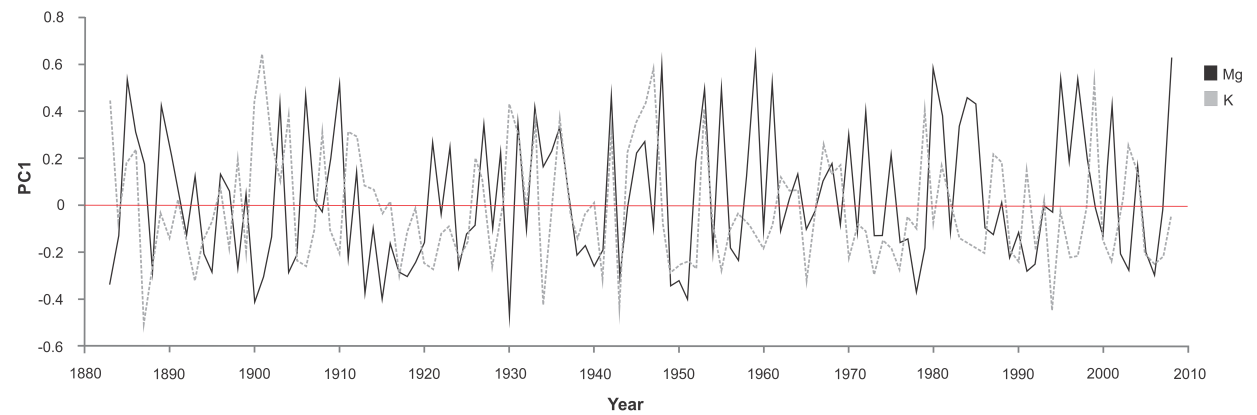

Figure 3. Variability of PC1 values in relation to age for magnesium (black) and potassium (gray). The red line marks the limit between positive and negative values.
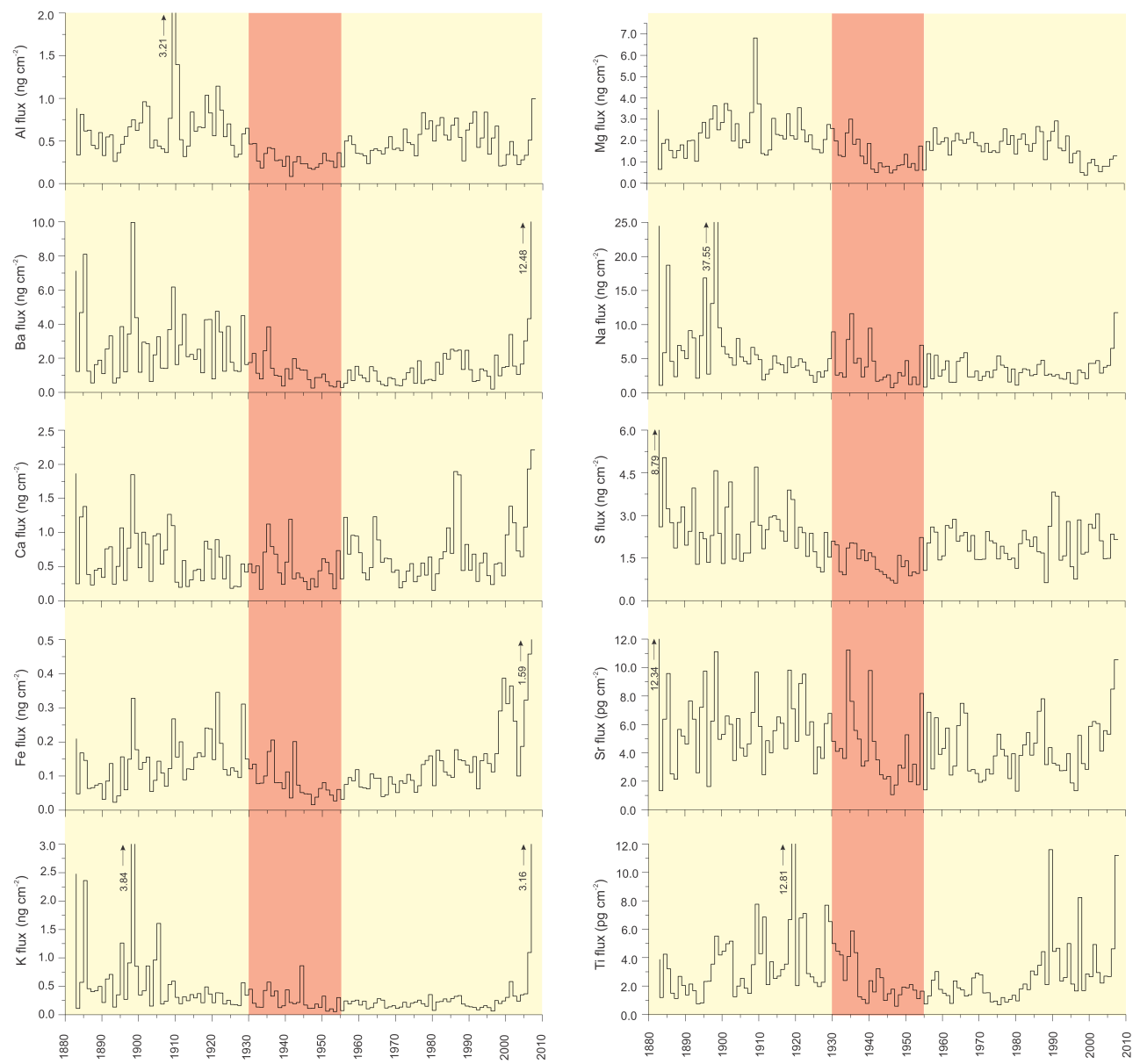

Figure 4. Annual fluxes of $\mathrm{Al}, \mathrm{Ba}, \mathrm{Ca}, \mathrm{Fe}, \mathrm{K}, \mathrm{Mg}, \mathrm{Na}, \mathrm{S}, \mathrm{Sr}$, and $\mathrm{Ti}$ in the $\mathrm{MJ}$ ice core (Mn is not shown). Colored bands define three distinct phases in the record from 1883 to 2008 .

Niño-Southern Oscillation (ENSO) is the variation in South Pacific sea surface temperature that induces regional-scale changes in atmospheric circulation in those latitudes. Several researchers have reported links between ENSO and aerosol deposition flux in Antarctica (Vance et al., 2013; Criscitiello et al., 2014). Below we will discuss in detail the influence of climate variables in the trace element fluxes presented.

\subsection{Interannual atmospheric variability}

Sea ice concentration trends are generally consistent with SST trends, such that regions of increasing (decreasing) sea ice are nearly always found in an environment of decreasing (increasing) SST. However, winds can influence sea ice concentration in several ways, including atmospheric ther- 

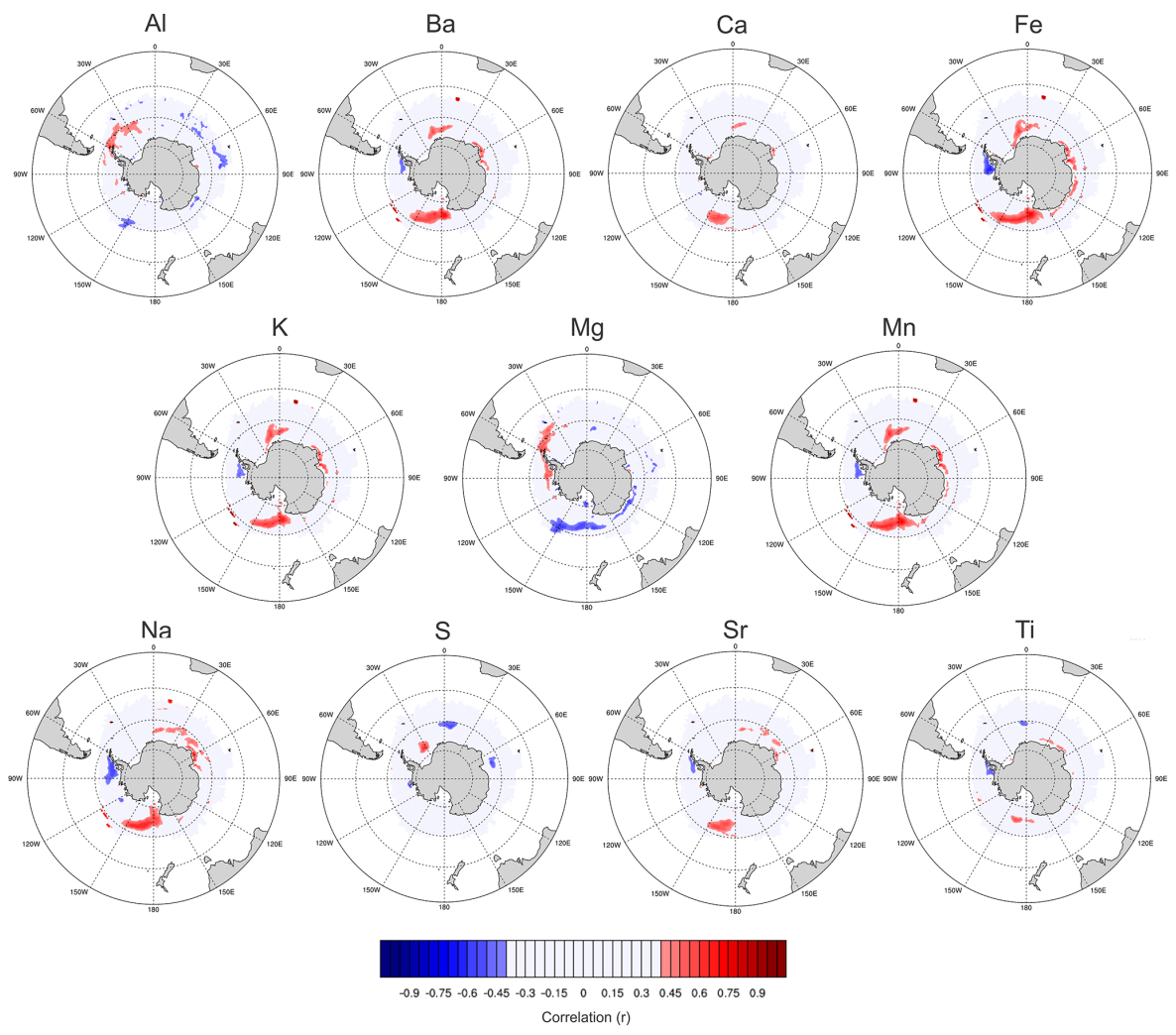

Figure 5. Correlation of the 1979-2008 ERA-Interim reanalysis sea ice concentration with the annually averaged trace element time series in the MJ ice core.

mal advection, oceanic currents, and wind-driven dynamic transport (Holland and Kwok, 2012). Schneider et al. (2011) suggest that atmospheric circulation trends have influenced both the sea ice concentration and the temperature trends in the Pacific sector of the Antarctic.

Correlations were made between annual means of reanalysis variables (SIC, SST, and $2 \mathrm{~m}$ air temperature) from the ERA-Interim product and the studied trace element annual average concentrations from 1979 to 2008. Observed correlations suggest a relationship between sea ice concentration, sea ice temperature, and aerosol transport to the ice core site. Figure 5 shows that correlations between SIC and most of the analyzed elements are positive $(r>0.55 ; p<0.05)$ in the Ross Sea and negative $(r>-0.45 ; p<0.05)$ in the Bellingshausen Sea, consistent with others authors (Simpkins et al., 2012; Turner et al., 2015a). Previous studies using satellite observations show a dipole structure in SIC with increasing sea ice in the Ross Sea (Stammerjohn et al., 2015) and decreasing sea ice in the Amundsen-Bellingshausen Sea (Holland and Kwok, 2012). This dipolar pattern is related to thermodynamic and dynamic forcing associated with variability in the pressure anomalies extending over the Amundsen Sea (Turner et al., 2015b).

The strongest positive correlations $(r=0.65 ; p<0.05)$ are in the region between 180 and $140^{\circ} \mathrm{W}$, suggesting that concentrations at the MJ site increase when SIC is high in the west Amundsen and Ross seas. This may indicate the dominant source area of the marine aerosols to the MJ area. Some studies show that processes associated with sea ice formation (e.g., frost flower formation, brine production, and blowing snow released from sea ice surfaces) are the dominant source of sea salt aerosols for Antarctica (Rankin et al., 2002; Kaspari et al., 2005; Criscitiello et al., 2013). Aluminum and magnesium exhibit negative correlations $(r=-0.55$; $p<0.05)$ in the Ross Sea region and positive correlations $(r=0.50 ; p<0.05)$ in the Antarctica Peninsula area. Aluminum in polar ice derives almost exclusively from crustal dust (McConnell et al., 2007), which explains the correlation difference between $\mathrm{Al}$ and other trace elements. However, $\mathrm{Mg}$ exhibits the same pattern observed for $\mathrm{Al}$, showing a relationship between the two elements. As previously presented in other studies, the nss fraction of $\mathrm{Mg}$ can be linked to insoluble silicate, soluble carbonate, or evaporite (e.g., gypsum, halite) minerals derived from terrestrial sites (McConnell et al., 2007; Kreutz and Koffman, 2013), which would explain the strong correlation with $\mathrm{Al}$ found. The nssMg fraction measured in this work corresponds to approximately $72 \%$ of the total concentration. This negative correlation is also related to a different seasonality pattern, with mineral dust 


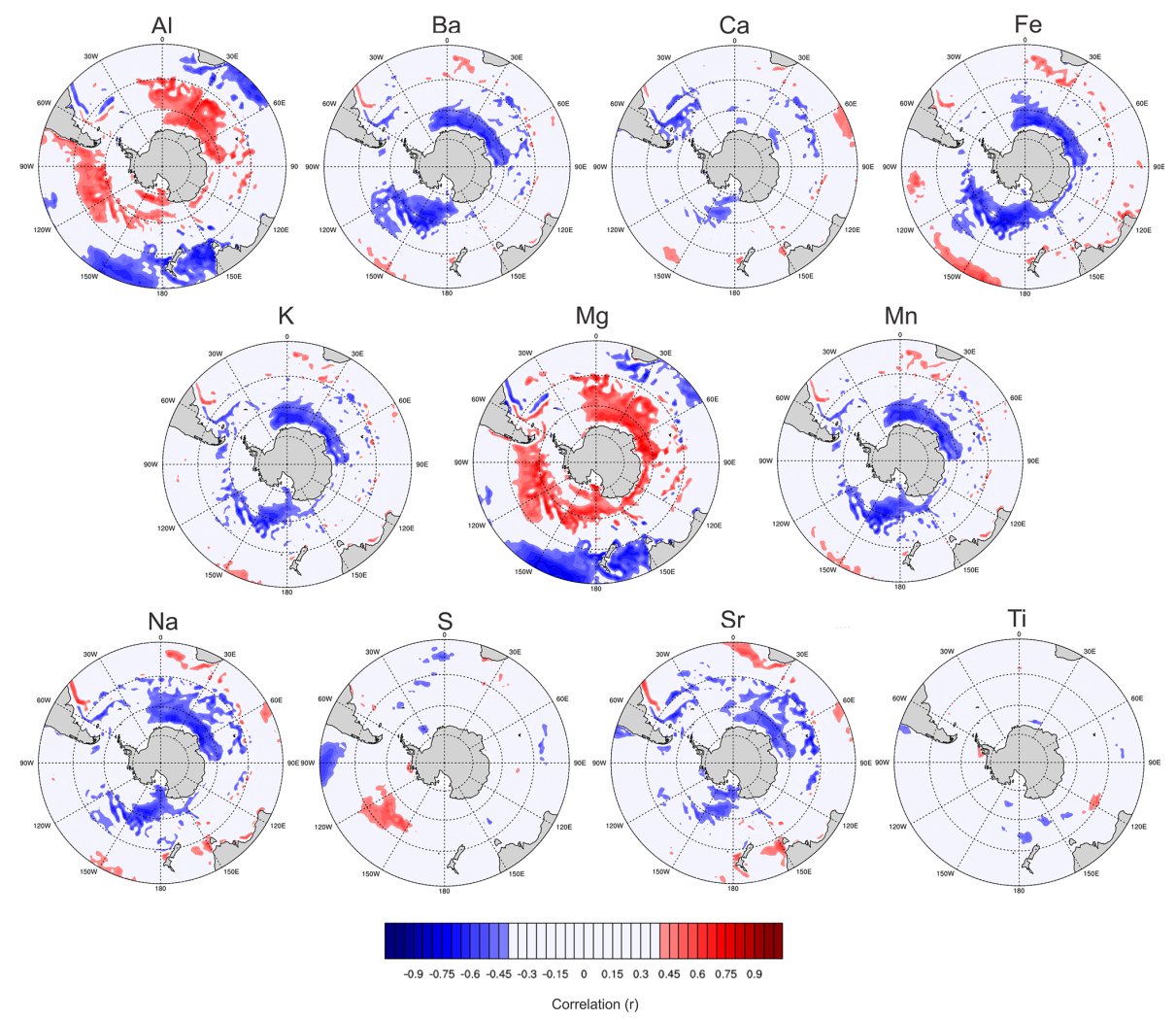

Figure 6. Correlation of the 1979-2008 ERA-Interim reanalysis sea surface temperature (SST) parameter with the annually averaged trace elements time series in the MJ ice core.

and marine aerosol peaks occurring in different periods of the year.

Figure 6 shows associations between SST and annual trace element concentrations. Negative correlations $(r>-0.70$; $p<0.05$ ) of SST in the Ross, Amundsen, and Bellingshausen seas with the trace element concentrations indicate increased transport of marine aerosols when the SST is cooler. Strong negative correlation $(r>-0.75 ; p<0.05)$ is also observed in the Weddell Sea and Indian Ocean. However, $\mathrm{Al}$ and $\mathrm{Mg}$ concentrations are positively correlated $(r>$ $0.65 ; p<0.05$ ) with the Ross, Bellingshausen, and Amundsen Sea as well as the southern Indian Ocean SST, indicating that $\mathrm{Al}$ and $\mathrm{Mg}$ concentrations increase when SST is high. Once more, $\mathrm{Al}$ and $\mathrm{Mg}$ exhibit a very strong relationship with each other and an inverse correlation with that presented by the other elements. In the case of these two elements, transport and deposition processes are associated with mineral dust seasonality pattern and influenced by warmer SST (usually associated with the spring-summer period) between the source and the MJ site.

The 1979-2008 correlations for $T_{2 \mathrm{~m}}$ are displayed in Fig. 7. Annual $T_{2 \mathrm{~m}}$ anomaly maps generally reveal weak negative anomalies $(r>-0.45 ; p<0.05)$ over the Ross and west Amundsen seas for the measured elements while show- ing low positive anomalies $(r>0.45 ; p<0.05)$ for $\mathrm{Al}$ and $\mathrm{Mg}$ specifically.

Ligtenberg et al. (2013) show that snowfall and $T_{2 \mathrm{~m}}$ on the Antarctic continent appear to be linked: periods with increasing $T_{2 \mathrm{~m}}$ coincide with periods of increasing snowfall. Changes in $T_{2} \mathrm{~m}$ show warmer and moister conditions extending considerably farther inland, consistent with enhanced air intrusions (Nicolas and Bromwich 2011). Changes in snow accumulation are also linked to the deepening of the Amundsen Sea Low (ASL), tropical SST, and large-scale atmospheric circulation (Thomas et al., 2015).

\subsection{Atmospheric transport to Mount Johns ice core site}

Atmospheric transport to Antarctica is dominated by the circumpolar westerly winds over the Southern Ocean and the permanent cyclone belt over the polar fronts (Hoskins and Hodges, 2005). The baroclinic zone, between 60 and $70^{\circ} \mathrm{S}$, is a very active cyclone-generating area due to the interaction of cold, dry air from the continent and relatively warmer, moist air from the Southern Ocean. The prevailing midlatitude westerlies direct the cyclones circulating around the Antarctic continent (King and Turner, 1997). The Antarctic Plateau is dominated by high pressure (anticyclonic, counterclockwise), and the wind regime is governed by katabatic winds (cold, dense air flowing downhill due to gravity). 


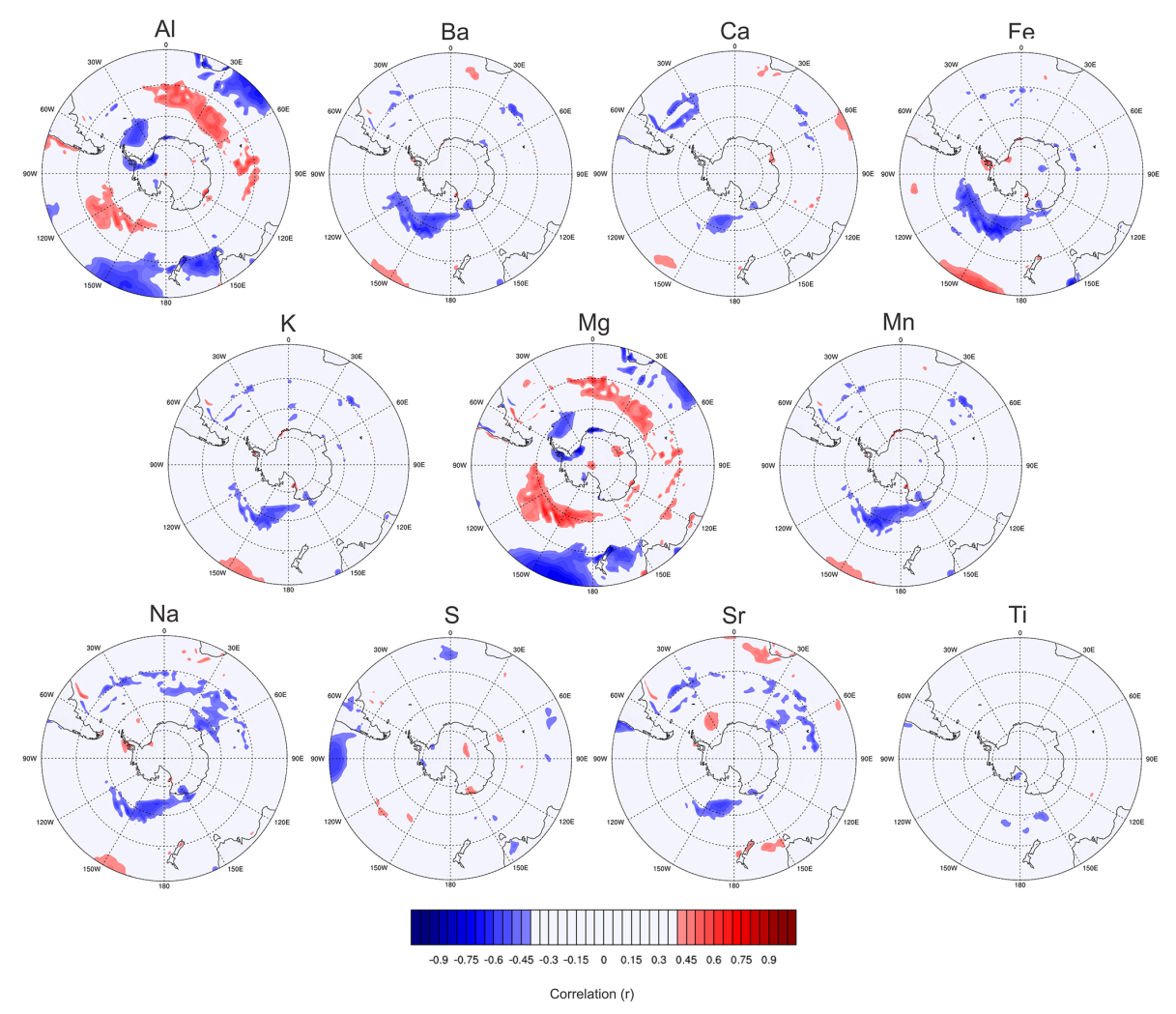

Figure 7. Correlation of the 1979-2008 ERA-Interim reanalysis $2 \mathrm{~m}$ air temperature parameter with the annually averaged trace elements time series in the MJ ice core.

The ASL is a major driver of West Antarctic climate variability (Turner et al., 2013). It is a mobile climatological lowpressure system located within $80-60^{\circ} \mathrm{S}, 170-298^{\circ} \mathrm{E}$ in the South Pacific (Kreutz et al., 2000; Hosking et al., 2013). The depth and location of the low-pressure center affect the climatic conditions and the strength of the westerlies along the coastal regions and the interior of West Antarctica (Ding et al., 2011; Schneider et al., 2012).

Back-trajectory modeling has been used to understand the synoptic controls on precipitation and the transport of trace elements to the study site. Here, we calculated 5-day backward trajectories using the NOAA HYSPLIT model and clustered the trajectories over austral spring (SeptemberNovember), summer (December-January), autumn (MarchMay), and winter (June-August) months. Daily simulations were generated during the 1979-2008 period. For the simulated trajectories, we have determined that five clusters are sufficient to capture the seasonal trajectory variability.

The MJ site receives the majority of air masses from the Amundsen Sea and, secondarily, from across the Antarctic Peninsula and Weddell Sea (Fig. 8). An additional source could be a continental local contribution. It is possible to identify two clusters with dominant westerly flow patterns ranging from fast (long) to slow-moving (short) depending on the season, one of which includes fast-moving trajecto- ries with strong cyclonic curvature around the Ross Ice Shelf (whole year), a group with direction that varies from westerly to northeasterly flow depending on the season, and a continental grouping that contains mainly katabatic flow paths from the interior. The clusters show that air masses circulate around the Antarctic continent until they are diverted to the interior, as synoptic storms, across the Amundsen and Bellingshausen seas. In some cases, the air masses arrive on the WAIS after being diverted across the Weddell Sea and traveling over the Filchner-Ronne Ice Shelf.

The trajectories are classified into two groups: (1) oceanic influenced (blue) and (2) continental influenced (red). These classifications are defined by characteristics identified from the mean trajectories of each cluster, speed (proportional to trajectory length), source region, and pathway. The frequency distribution of cluster classes for the 1979-2008 period shows distinct seasonality between the austral summer and other seasons, with comparatively stronger westerly transport in the cold months and secondary northeasterly transport in the warm months. On average, the oceanic group has a maximum seasonal frequency in winter, while the continental group peaks in winter-spring. During the summer, the trajectories generally are slow moving (short) and are more locally influenced than in others seasons. 

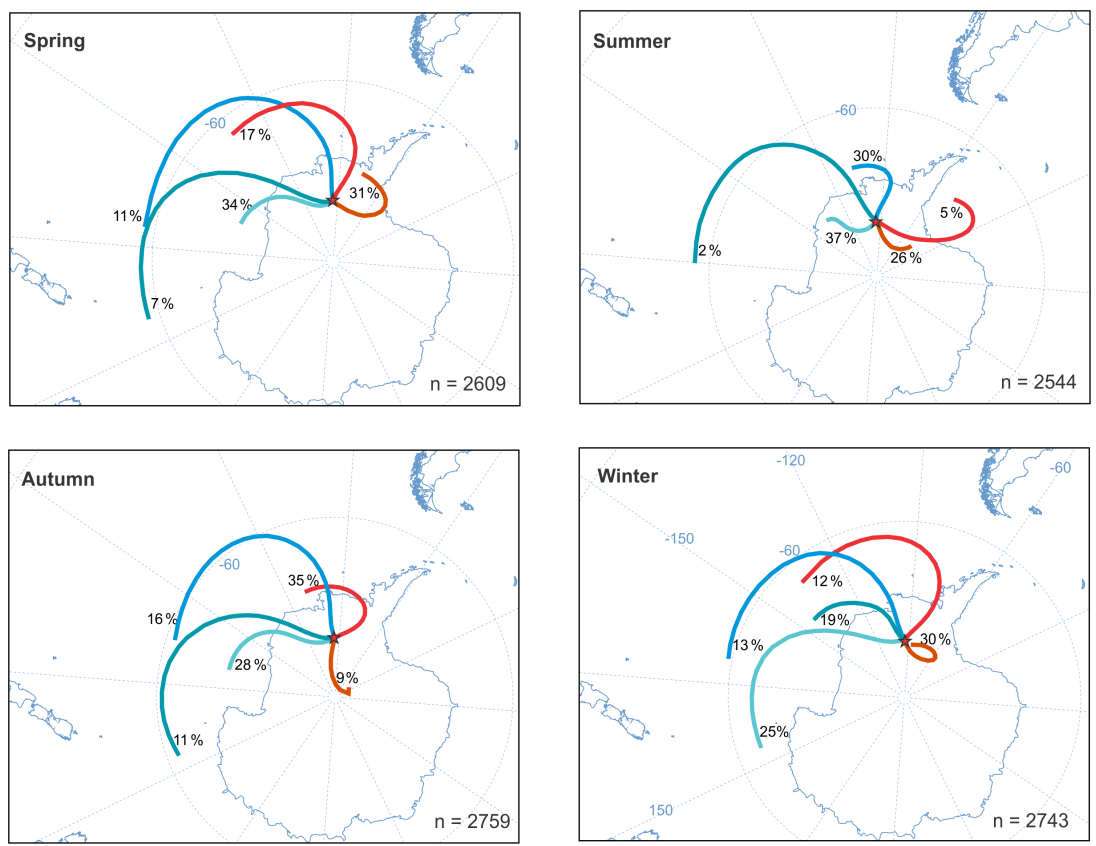

Figure 8. HYSPLIT seasonal clusters of daily 5-day back trajectories from 1979 to 2008 arriving at the Mount Johns ice core site, West Antarctica. Percentage of daily trajectories included in each cluster is indicated; number of daily trajectories for each season is indicated at the bottom right of each panel. Blue represents oceanic group clusters, while red shows the continental group clusters. Trajectories calculated using the NOAA HYSPLIT model (version 4.9).

\subsection{Relationships between atmospheric circulation, temperature, and sea ice concentration}

The highest concentrations of trace elements in the winter are associated with air masses clustered within the oceanic trajectories. Low-pressure centers over the BellingshausenAmundsen Sea are associated with cold temperatures and sea ice formation in the region (Bromwich et al., 2013; Criscitiello et al., 2014). Seasonal and interannual variability of the trace element concentrations is also likely due to wind speed and transport efficiency at the time of deposition. Hoskins and Hodges (2005) suggest that storminess over the Southern Ocean and the strength of inland transport, both of which are enhanced during winter, can explain the winter maxima deposition in the WAIS. The wind associated with the low-pressure systems over the BellingshausenAmundsen Sea would facilitate the generation and transport of sea salt aerosols from either an open-ocean or a sea ice source (Bromwich et al., 2013; Criscitiello et al., 2014; Pasteris et al., 2014). The westward extent of trajectories from winter (maximum sea ice area) to spring (maximum sea ice retreat) is between 180 and $140^{\circ} \mathrm{W}$, coincident with the area of greatest correlation between trace elements concentrations and SIC, SST, and $T_{2} \mathrm{~m}$. The mechanism for deposition of trace elements at the MJ site is intrinsically linked with enhanced sea ice production in the Amundsen-Ross seas. Thus, not only is there a clear mechanism for trace elements transport to the MJ site, but the factors governing this transport (for example, local wind conditions and temperature) are also related to the sea ice concentration itself.

These air masses also have the potential to capture impurities transported over the South Pacific from midlatitude continental regions such as South America or Australia. Moreover, winds remobilize mineral dust from ice-free areas in the WAIS, for example trajectories crossing Marie Byrd Land, Ellsworth Land, the Antarctic Peninsula, and the Weddell Sea. Li et al. (2008) show that due to the prevailing westerlies the distribution and deposition of dust have an eastward transport so that half of the Atlantic Ocean and Indian Ocean are influenced by South American dust and the Pacific region is influenced by Australian dust. Modeling studies of dust transport to Antarctica (Krinner et al., 2010) show that the annual mean concentration of dust in West Antarctica (particularly Marie Byrd Land) is mostly represented by dust originating from Australia. This is in agreement with Neff and Bertler (2015) and Tuohy et al. (2015), who show dust transportation from Australia and New Zealand to the South Pacific. As observed previously in other ice core sites from the WAIS (Dixon et al., 2011; Koffman et al., 2014a; Neff and Bertler, 2015), mineral dust reaching the MJ ice core site is unlikely to be associated with a single dust source due to mixing along the transport path from presumed continental sources. In previous work at the MJ core site, Cataldo et al. (2013) found particle sizes ranging from 1.1 to $2.4 \mu \mathrm{m}$. Based on these data we assume that the concentrations are more influenced by remote continental sources than local 
sources. However, we do not disregard the possibility that local contributions can be a secondary source of dust.

Previous studies have also identified a teleconnection between the tropical Pacific Ocean and aerosol deposition in Antarctica (Vance et al., 2013; Criscitiello et al., 2014). SST anomalies in areas of strong tropical convection in the central tropical Pacific have a significant influence on the atmospheric circulation in the Bellingshausen-Amundsen Sea area through the generation of a large-scale atmospheric wave train (Lachlan-Cope and Connolley, 2006; Ding et al., 2011). The wave train pattern is prominent in winter and spring months (Lachlan-Cope and Connolley, 2006). Since sea salt aerosols are deposited throughout the year, notably in winter, it is expected that tropical forcing and atmospheric Rossby waves would influence trace element concentrations. However, the elements of crustal origin presented different variability with maximum concentration in periods of lower SIC and higher temperature (usually associated with the spring-summer). Mineral dust deposition at other locations in Antarctica also exhibits seasonal variability with a maximum in summer, e.g., Berkner Island (Bory et al., 2010), Windless Bight, McMurdo Sound (Dunbar et al., 2009), and the South Pole (Legrand and Kirchner, 1988).

The strong negative correlation between trace element concentrations and SST further demonstrates that concentrations contained in the $\mathrm{MJ}$ ice core record provide an indication of past variability. Based on significant negative correlations with SST, and supported by annual variability of $\delta^{18} \mathrm{O} /{ }^{16} \mathrm{O}$ (Fig. S2), we suggest that high concentrations observed before 1930 in our ice core record are directly related to cooler SST affecting atmospheric transport in the Amundsen-Ross Sea region. We assume that the low concentrations observed later (1930-1955) are consistent with a warming in the region. Schneider and Steig (2008) show extreme positive anomalies (representative of West Antarctic surface temperature) during the $1936-1945$ period. The authors interpreted these anomalies as indicative of strong teleconnections in part driven by the ENSO (1939-1942). The second increasing trend observed for $\mathrm{Al}, \mathrm{Ba}, \mathrm{Fe}, \mathrm{Mg}$, $\mathrm{S}$, and Ti (between 1955 and 1992), when compared with the $\delta^{18} \mathrm{O}$ record, is also associated with a period of cooling in the $\mathrm{MJ}$ area or in the region where these aerosols are generated. Jones et al. (2016) show a cooling of SST in the Ross sector during the study time (1979-2014); this may be related to the increase of concentrations, since our correlations have pointed to this region as a source area of marine aerosols. This cooling is followed by a warming period in recent years in the MJ record (associated with decreased concentrations of $\mathrm{Al}, \mathrm{Mg}$, and S). Therefore, it seems possible that different trace element concentrations respond to different forcing on different timescales.

The Antarctic climate system is strongly interconnected; regional and seasonal complexity as well as physical relationships between different climate variables must be taken into account to identify the mechanisms driving the produc- tion, transport, and deposition of trace elements in the WAIS. While these results are promising, further work involving assimilation methods using ice core proxy records and climate simulations in order to best reconstruct the past state of the Antarctic atmospheric circulation is required.

\section{Conclusions}

Using high-resolution ICP-SFMS, several trace elements were measured in an ice core from the WAIS and used to evaluate inputs from natural aerosol emission sources. It was found that natural contributions from mineral dust are important sources of $\mathrm{Al}, \mathrm{Mg}$, and $\mathrm{Ti}$, while marine aerosols from the open sea and sea ice in the South Pacific are important sources of $\mathrm{Na}, \mathrm{Sr}$, and $\mathrm{Ca}$ over the MJ site. However, $\mathrm{Ba}, \mathrm{Fe}$, $\mathrm{K}, \mathrm{Mn}$, and $\mathrm{S}$ appear to be from mixed sources (mineral dust and sea salt aerosols). Additionally, $\mathrm{S}$ and $\mathrm{Mn}$ exhibit important volcanic contribution, and $\mathrm{S}$ has a considerable biogenic input in the summer season. Utilizing back trajectories from HYSPLIT, we identify two dominant air mass trajectory clusters: marine and continental. The analysis shows distinct differences between seasons, relatively stronger westerly transport during the winter months and secondary northeasterly transport during the summer months. During the summer, the trajectories present slow-moving (short) transport and are locally influenced when compared to other seasons. Based on particle size $(1.1-2.4 \mu \mathrm{m})$ for $\mathrm{MJ}$ ice core and the air mass trajectory, we conclude that the trace element concentrations are influenced by remote continental sources more so than local sources, although we do not ignore the possibility that local contributions can be a secondary source of mineral dust.

Our reanalysis-element correlations suggest that marinederived trace element concentrations are strongly influenced by SIC and SST anomalies. The results show that seasonal concentration maxima in sea salt elements correlate well with the SIC winter maxima. The strongest correlations are in the region between 180 and $140^{\circ} \mathrm{W}$, suggesting that elemental concentrations at the MJ site increase when SIC is high in the west Amundsen and Ross seas. This may indicate the dominant source of the marine aerosols over the MJ site. Correlations of SST in the Ross, Amundsen, and Bellingshausen seas with the MJ site indicate increased transport of marine aerosols when the SST is relatively cooler. Previous studies indicate that wind associated with low-pressure systems over the Bellingshausen-Amundsen Sea facilitates the generation and transport of sea salt aerosols from either an open-ocean or a sea ice source (Bromwich et al., 2013; Criscitiello et al., 2014; Pasteris et al., 2014) and also affect the mineral dust transport from circum-Antarctic continents to the Southern Ocean and WAIS (Neff and Bertler, 2015).

We show that both sources and transport of mineral dust and marine aerosols to West Antarctica are controlled by the climate variables in response to remote atmospheric forcing. While these results are promising, further work is needed to 
obtain a more detailed picture of past variability and its relationship with regional aerosol transport.

Data availability. Data are available at NOAA: https://www.ncdc. noaa.gov/paleo-search/study/22271.

\section{The Supplement related to this article is available online at https://doi.org/10.5194/tc-11-1537-2017-supplement.}

Competing interests. The authors declare that they have no conflict of interest.

Acknowledgements. This research is part of the Brazilian Antarctic Program (PROANTAR) and was financed with funds from the Ciência Sem Fronteiras (CAPES - CSF SDW no. 0088/13-7) and the National Council for Scientific and Technological Development (CNPq), project 407888/2013-6.

Edited by: Joel Savarino

Reviewed by: two anonymous referees

\section{References}

Albani, S., Mahowald, N. M., Delmonte, B., Maggi, V., and Winckler, G: Comparing modeled and observed changes in mineral dust transport and deposition to Antarctica between the Last Glacial Maximum and current climates, Clim. Dynam., 38, 1731-1755, 2012.

Bamber, J. L., Riva, R. E. M., Vermeersen, B. L. A., and LeBrocq, A. M.: Reassessment of the potential sea-level rise from a collapse of the West Antarctic Ice Sheet, Science, 324, 901-903, https://doi.org/10.1126/science.1169335, 2009.

Becagli, S., Proposito, M., Benassai, S., Gragnani, R., Magand, O., Traversi, R., and Udisti, R.: Spatial distribution of biogenic sulphur compounds (MSA, nssSO ${ }_{4}^{2-}$ ) in the northern Victoria LandDome C-Wilkes Land area, East Antarctica, Ann. Glaciol., 41, 23-31, 2005.

Bory, A., Wolff, E., Mulvaney, R., Jagoutz, E., Wegner, A., Ruth, U., and Elderfield, H.: Multiple sources supply eolian mineral dust to the Atlantic sector of coastal Antarctica: Evidence from recent snow layers at the top of Berkner Island ice sheet, Earth Planet. Sc. Lett., 291, 138-148, 2010.

Boutron, C. F. and Patterson, C. C.: Lead concentration changes in Antarctic ice during the Wisconsin/Holocene transition, Nature, 323, 222-225, 1986.

Bracegirdle, T. J. and Marshall, G. J.: The reliability of Antarctic tropospheric pressure and temperature in the latest global reanalyses, J. Climate, 25, 7138-7146, 2012.

Bromwich, D. H. and Fogt, R. L.: Strong trends in the skill of the ERA-40 and NCEP/NCAR reanalyses in the high and middle latitudes of the Southern Hemisphere, 1958-2001, J. Climate, 17, 4603-4619, 2004.
Bromwich, D. H., Nicolas, J. P., Monaghan, A. J., Lazzara, M. A., Keller, L. M., Weidner, G. A., and Wilson, A. B.: Central West Antarctica among the most rapidly warming regions on Earth, Nat. Geosci., 6, 139-145, 2013.

Cataldo, M., Evangelista, H., Simões, J. C., Godoi, R. H. M., Simmonds, I., Hollanda, M. H., Wainer, I., Aquino, F., and Van Grieken, R.: Mineral dust variability in central West Antarctica associated with ozone depletion, Atmos. Chem. Phys., 13, 2165-2175, https://doi.org/10.5194/acp-13-2165-2013, 2013.

Chewings, J. M., Atkins, C. B., Dunbar, G. B., and Golledge, N. R.: Aeolian sediment transport and deposition in a modern highlatitude glacial marine environment, Sedimentology, 61, 15351557, https://doi.org/10.1111/sed.12108, 2014.

Criscitiello, A. S., Das, S. B., Evans, M. J., Frey, K. E., Conway, H., Joughin, I., Medley, B., and Steig, E.: Ice sheet record of recent sea-ice behavior and polynya variability in the Amundsen Sea, West Antarctica, J. Geophys. Res.-Oceans, 118, 118-130, 2013.

Criscitiello, A. S., Das, S. B., Karnauskas, K. B., Evans, M. J., Frey, K. E., Joughin, I., Steig, E. J., McConnell, J. R., and Medley, B.: Tropical Pacific influence on the source and transport of marine aerosols to West Antarctica, J. Climate, 27, 1343-1363, 2014.

Dee, D. P., Uppala, S. M., Simmons, A. J., Berrisford, P., Poli, P., Kobayashi, S., Andrae, U., Balmaseda, M. A., Balsamo, G., Bauer, P., Bechtold, P., Beljaars, A. C. M., Van de Berg, L., Bidlot, J., Bormann, N., Delsol, C., Dragani, R., Fuentes, M., Geer, A. J., Haimberger, L., Healy, S. B., Hersbach, H., Hólm, E. V., Isaksen, L., Kållberg, P., Köhler, M., Matricardi, M., McNally, A. P., Monge-Sanz, B. M., Morcrette, J.-J., Park, B.-K., Peubey, C., de Rosnay, P., Tavolato, C., Thépaut, J.-N., and Vitart, F.: The ERA-Interim reanalysis: configuration and performance of the data assimilation system, Q. J. Roy. Meteor. Soc., 137, 553-597, 2011.

Delmonte, B., Andersson P. S., Schöberg, H., Hansson, M., Petit, J-R., Delmas, R., Gaiero, D. M., Maggi, V., and Frezzotti, M.: Geographic provenance of aeolian dust in East Antarctica during Pleistocene glaciations: preliminary results from Talos Dome and comparison with East Antarctic and new Andean ice core data, Quaternary Sci. Rev., 29, 256-264, 2010.

Delmonte, B., Baroni, C., Andersson, P. S., Narcisi, B., Salvatore, M. C., Petit, J-R., Scarchilli, C., Frezzotti, M., Albani, S., and Maggi, V.: Modern and Holocene Aeolian dust variability from Talos Dome (northern Victoria Land) to the interior of the Antarctic ice sheet, Quaternary Sci. Rev., 64, 76-89, 2013.

Ding, Q., Steig, E. J., Battisti, D. S., and Küttel, M.: Winter warming in West Antarctica caused by central tropical Pacific warming, Nat. Geosci., 4, 398-403, https://doi.org/10.1038/ngeo1129, 2011.

Dixon, D. A., Mayewski, P. A., Goodwin, I. D., Marshall, G. J., Freeman, R., Maasch, K. A., and Sneed, S. B.: An ice-proxy for northerly air mass incursions into West Antarctica, Int. J. Climatol., 32, 1455-1465, https://doi.org/10.1002/joc.2371, 2011.

Dixon, D. A., Mayewski, P. A., Korotkikh, E., Sneed, S. B., Handley, M. J., Introne, D. S., and Scambos, T. A.: Variations in snow and firn chemistry along US ITASE traverses and the effect of surface glazing, The Cryosphere, 7, 515-535, https://doi.org/10.5194/tc-7-515-2013, 2013.

Draxler, R. R.: HYSPLIT4 user's guide, technical memorandum, NOAA, Silver Spring, Md, 1999. 
Draxler, R. R., Ginoux, P., and Stein, A. F.: An empirically derived emission algorithm for wind-blown dust, J. Geophys. Res., 115, D16212, https://doi.org/10.1029/2009JD013167, 2010.

Duce, R. A., Hoffman, G. L., and Zoller, W. H.: Atmospheric tracemetals at remote northern and southern hemisphere sites: pollution or natural?, Science, 187, 59-61, 1975.

Dunbar, G. B., Bertler, N. A. N., and McKay, R. M.: Sediment flux through the McMurdo Ice Shelf in Windless Bight, Antarctica, Global Planet. Change, 69, 87-93, 2009.

Favier, L., Durand, G., Cornford, S. L., Gudmundsson, G. H., Gagliardini, O., Gillet-Chaulet, F., Zwinger, T., Payne, A. J., and Le Brocq, A. M.: Retreat of Pine Island Glacier controlled by marine ice-sheet instability, Nature Climate Change, 4, 117-121, https://doi.org/10.1038/NCLIMATE2094, 2014.

Fischer, H., Traufetter, F., Oerter, H., Weller, R., and Miller, H.: Prevalence of the Antarctic Circumpolar Wave over the last two millennia recorded in Dronning Maud Land ice, Geophys. Res. Lett., 31, L08202, https://doi.org/10.1029/2003GL019186, 2004.

Fretwell, P., Pritchard, H. D., Vaughan, D. G., Bamber, J. L., Barrand, N. E., Bell, R., Bianchi, C., Bingham, R. G., Blankenship, D. D., Casassa, G., Catania, G., Callens, D., Conway, H., Cook, A. J., Corr, H. F. J., Damaske, D., Damm, V., Ferraccioli, F., Forsberg, R., Fujita, S., Gim, Y., Gogineni, P., Griggs, J. A., Hindmarsh, R. C. A., Holmlund, P., Holt, J. W., Jacobel, R. W., Jenkins, A., Jokat, W., Jordan, T., King, E. C., Kohler, J., Krabill, W., Riger-Kusk, M., Langley, K. A., Leitchenkov, G., Leuschen, C., Luyendyk, B. P., Matsuoka, K., Mouginot, J., Nitsche, F. O., Nogi, Y., Nost, O. A., Popov, S. V., Rignot, E., Rippin, D. M., Rivera, A., Roberts, J., Ross, N., Siegert, M. J., Smith, A. M., Steinhage, D., Studinger, M., Sun, B., Tinto, B. K., Welch, B. C., Wilson, D., Young, D. A., Xiangbin, C., and Zirizzotti, A.: Bedmap2: improved ice bed, surface and thickness datasets for Antarctica, The Cryosphere, 7, 375-393, https://doi.org/10.5194/tc-7-375-2013, 2013.

Gabrielli, P., Cozzi, G., Torcini, S., Cescon, P., and Barbante, C.: Trace elements in winter snow of the Dolomites (Italy): A statistical study of natural and anthropogenic contributions, Chemosphere, 72, 1504-1509, 2008.

Gaiero, D. M., Brunet, F., Probst, J.-L., and Depetris, P. J.: A uniform isotopic and chemical signature of dust exported from Patagonia: Rock sources and occurrence in Southern environments, Chem. Geol., 238, 107-120, 2007.

Ginot, P., Stampfli, F., Stampfli, D., Schwikowski, M., and Gäggeler, H. W.: FELICS, a new ice core drilling system for high-altitude glaciers, Memoirs of National Institute of Polar Research, Tokyo, Special Issue, 56, 38-48, 2002.

Hinkley, T. K., Lamothe, P. J., Wilson, S. A., Finnegan, D. L., and Gerlach, T. M.: Metal emissions from Kilauea, and a suggested revision of the estimated worldwide metal output by quiescent degassing of volcanoes, Earth Planet. Sc. Lett., 170, 315-325, 1999.

Holland, P. R. and Kwok, R.: Wind-driven trends in Antarctic sea-ice drift, Nat. Geosci., 5, 872-875, https://doi.org/10.1038/ngeo1627, 2012.

Hoskins, B. J. and Hodges, K. I.: A new perspective on Southern Hemisphere storm tracks, J. Climate, 18, 4108-4129, 2005.

Hosking, J. S., Orr, A., Marshall, G. J., Turner, J., and Phillips, T.: The influence of the Amundsen-Bellingshausen Seas low on the climate of West Antarctica and its representation in coupled climate model simulations, J. Climate, 26, 6633-6648, 2013.

Hur, S., Cunde, X., Hong, S., Barbante, C., Gabrielli, P., Lee, K., Boutron, C. F., and Ming, Y.: Seasonal patterns of heavy metal deposition to the snow on Lambert Glacier basin, East Antarctica, Atmos. Environ., 41, 8567-8578, 2007.

Jones, J. M., Gille, S. T., Goosse, H., Abram, N. J., Canziani, P. O., Charman, D. J., Clem, K. R., Crosta, X., Lavergne, C., Eisenman, I., England, M. H., Fogt, R. L., Frankcombe, L. M., Marshall, G. J., Masson-Delmotte, V., Morrison, A. K., Orsi, A. J., Raphael, M. N., Renwick, J. A., Schneider, D. P., Simpkins, G. R., Steig, E. J., Stenni, B., Swingedouw, D., and Vance, T. R.: Assessing recent trends in high-latitude Southern Hemisphere surface climate, Nature Climate Change, 6, 917-936, 2016.

Kalnay, E., Kanamitsu, M., Kistler, R., Collins, W., Deaven, D., Gandin, L., Iredell, M., Saha, S., White, G., Woollen, J., Zhu, Y., Chelliah, M., Ebisuzaki, W., Higgins, W., Janowiak, J., Mo, K. C., Ropelewski, C., Wang, J., Leetmaa, A., Reynolds, R., Jenne, R., and Joseph, D.: The NCEP/NCAR 40-year reanalysis project, B. Am. Meteorol. Soc., 77, 437-471, 1996.

Kaspari, S., Dixon, D. A., Sneed, S. B., and Handley, M. J.: Sources and transport pathways of marine aerosol species into West Antarctica, Ann. Glaciol., 41, 1-9, 2005.

King, J. C. and Turner, J.: Antarctic Meteorology and Climatology, University Press Cambridge, Cambridge, 409 pp., 1997.

Kistler, R., Kalnay, E., Collins, W., Saha, S., White, G., Woollen, J., Chelliah, M., Ebisuzaki, W., Kanamitsu, M., Kousky, V., van den Dool, H., Jenne, R., and Fiorino, M.: The NCEP-NCAR 50year reanalysis: Monthly means CD-ROM and documentation, B. Am. Meteorol. Soc., 82, 247-267, 2001.

Koffman, B. G., Kreutz, K. J., Breton, D. J., Kane, E. J., Winski, D. A., Birkel, S. D., Kurbatov, A. V., and Handley, M. J.: Centennial-scale variability of the Southern Hemisphere westerly wind belt in the eastern Pacific over the past two millennia, Clim. Past, 10, 1125-1144, https://doi.org/10.5194/cp-10-11252014, 2014a.

Koffman, B. G., Handley, M. J., Osterberg, E. C., Wells, M. L., and Kreutz, K. J.: Dependence of ice-core relative trace-element concentration on acidification, J. Glaciol., 60, 103-112, 2014b.

Kreutz, K. J. and Koffman, B. G.: Glaciochemistry, Encyclopedia of Quaternary Science, 2, 326-333, 2013.

Kreutz, K. J., Mayeswski, P. A., Pittalwala, I. I., Meeker, L. D., Twickler, M. S., and Whitlow, S. I.: Sea level pressure variability in the Amundsen Sea region inferred from a West Antarctic glaciochemical record, J. Geophys. Res., 105, 4047-4059, 2000.

Krinner, G., Petit, J.-R., and Delmonte, B.: Altitude of atmospheric tracer transport towards Antarctica in present and glacial climate, Quaternary Sci. Rev., 29, 274-284, 2010.

Kurbatov, A. V., Mayewski, P. A., and Abdul Jawad, B. S.: Ice Core Dating Software for interactive dating of Ice Cores, Eos, T. Am. Geophys. Un., Fall Meeting Supplement, 86, Abstract PP33C1603, 2005.

Lachlan-Cope, T. and Connolley, W.: Teleconnections between the tropical Pacific and the Amundsen-Bellingshausen Sea: role of the El Niño/Southern Oscillation, J. Geophys. Res., 111, D23101, https://doi.org/10.1029/2005JD006386, 2006.

Legrand, M. and Kirchner, S.: Polar atmospheric circulation and chemistry of recent (1957-1983) South Polar precipitation, Geophys. Res. Lett., 15, 879-992, 1988. 
Legrand, M. and Mayewski, P.: Glaciochemistry of polar cores: A review, Rev. Geophys., 35, 219-243, 1997.

Li, F., Ginoux, P., and Ramaswamy, V.: Distribution, transport, and deposition of mineral dust in the Southern Ocean and Antarctica: Contribution of major sources, J. Geophys. Res., 113, D10207, https://doi.org/10.1029/2007JD009190, 2008.

Li, F., Ginoux, P., and Ramaswamy, V.: Transport of Patagonian dust to Antarctica, J. Geophys. Res., 115, D18217, https://doi.org/10.1029/2009JD012356, 2010.

Lide, D. R. (Ed.): Abundance of Elements in the Earth's crust and in the sea, in: CRC Handbook of Chemistry and Physics, Internet Version 2005, Boca Raton, CRC Press, 14-17, 2005.

Ligtenberg, S. R. M., van de Berg, W. J., van den Broeke, M. R., Rae, J. G. L., and van Meijgaard, E.: Future surface mass balance of the Antarctic ice sheet and its influence on sea level change, simulated by a regional atmospheric climate model, Clim. Dynam., 41, 867-884, https://doi.org/10.1007/s00382-013-1749-1, 2013.

Loska, K. and Wiechula, D.: Application of principal component analysis for the estimation of source of heavy metal contamination in surface sediments from the Rybnik Reservoir, Chemosphere, 51, 723-733, 2003.

Mahowald, N., Albani, S., Kok, J. F., Engelstaeder, S., Scanza, R., Ward, D. S., and Flanner, M. G.: The size distribution of desert dust aerosols and its impact on the Earth system, Aeolian Res., 15, 53-71, 2014.

Markle, B. R., Bertler, N. A. N., Sinclair, K. E., and Sneed, S. B.: Synoptic variability in the Ross Sea region, Antarctica, as seen from back-trajectory modeling and ice core analysis, J. Geophys. Res., 117, D02113, https://doi.org/10.1029/2011JD016437, 2012.

McConnell, J. R., Aristarain, A. J., Banta, J. R., Edwards, P. R., and Simões, J. C.: 20th-Century doubling in dust archived in an Antarctic Peninsula ice core parallels climate change and desertification in South America, P. Natl. Acad. Sci. USA, 104, $5743-$ 5748, 2007.

Neff, P. D., and Bertler, N. A. N.: Trajectory modeling of modern dust transport to the Southern Ocean and Antarctica, J. Geophys. Res.-Atmos., 120, 9303-9322, https://doi.org/10.1002/2015JD023304, 2015.

Nicolas, J. P. and Bromwich, D. H.: Climate of West Antarctica and influence of marine air intrusions, J. Climate, 24, 49-67, 2011.

Osterberg, E. C.: North Pacific late Holocene climate variability and atmospheric composition, $\mathrm{PhD}$ thesis, University of Maine, Orono, USA, 161 pp., 2007.

Osterberg, E. C., Handley, M. J., Sneed, S. B., Mayewski, P. A., and Kreutz, K. J.: Continuous ice core melter system with discrete sampling for major ion, trace element, and stable isotope analysis, Environ. Sci. Technol., 40, 3355-3361, 2006.

Palmer, A. S., Morgan, V. I., Curran, M. A. J., Van Ommen, T. D., and Mayewski, P. A.: Antarctic volcanic flux ratios from Law Dome ice cores, Ann. Glaciol., 35, 329-332, 2002.

Pasteris, D. R., McConnell, J. R., Das, S. B., Criscitiello, A. S., Evans, M.'J., Maselli, O. J., Sigl, M., and Layman, L.: Seasonally resolved ice core records from West Antarctica indicate a sea ice source of sea-salt aerosol and a biomass burning source of ammonium, J. Geophys. Res.-Atmos., 119, 9168-9182, 2014.

Petit, J. R. and Delmonte, B.: A model for large glacial-interglacial climate-induced changes in dust and sea salt concentrations in deep ice cores (central Antarctica): palaeoclimatic implications and prospects for refining ice core chronologies, Tellus B, 61, 768-790, https://doi.org/10.1111/j.1600-0889.2009.00437.x, 2009.

Planchon, F. A. M., Boutron, C. F., Barbante, C., Cozzi, G., Gaspari, V., Wolff, E. W., Ferrari, C. P., and Cescon, P.: Changes in heavy metals in Antarctic snow from Coats Land since the mid-19th to the late-20th century, Earth Planet. Sc. Lett., 200, 207-222, 2002.

Pritchard, H. D., Arthern, R. J., Vaughan, D. G., and Edwards, L. A.: Extensive dynamic thinning on the margins of the Greenland and Antarctic ice sheets, Nature, 461, 971-975, https://doi.org/10.1038/nature08471, 2009.

Pritchard, H. D., Ligtenberg, S. R. M., Fricker, H. A., Vaughan, D. G., van den Broeke, M. R., and Padman, L.: Antarctic ice-sheet loss driven by basal melting of ice shelves, Nature, 484, 502-505, https://doi.org/10.1038/nature10968, 2012.

Prospero, J. M., Ginoux, P., Torres, O., Nicholson, S. E., and Gill, T. E.: Environmental characterization of global sources of atmospheric soil dust identified with the Nimbus 7 total ozone mapping spectrometer (TOMS) absorbing aerosol product, Rev. Geophys., 40, 1002, https://doi.org/10.1029/2000RG000095, 2002.

Rankin, A. M., Wolff, E. W., and Martin, S.: Frost flowers: Implications for tropospheric chemistry and ice core interpretation, J. Geophys. Res., 107, 4683, https://doi.org/10.1029/2002JD002492, 2002.

Revel-Rolland, M., de Deckker, P., Delmonte, B., Hesse, P. P., Magee, J. W., Basile-Doelsch, I., Grousset, F., and Bosch, D.: Eastern Australia: A possible source of dust in East Antarctica interglacial ice, Earth Planet. Sc. Lett., 249, 1-13, 2006.

Rhodes, R. H., Baker, J. A., Millet, M.-A., and Bertler, N. A. N.: Experimental investigation of the effects of mineral dust on the reproducibility and accuracy of ice core trace element analyses, Chem. Geol., 286, 207-221, 2011.

Rignot, E., Bamber, J. L., Van den Broeke, M. R., Davis, C., Li, Y., Van de Berg, W. J., and Meijgaard, E. V.: Recent Antarctic ice mass loss from radar interferometry and regional climate modeling, Nat. Geosci., 1, 106-110, https://doi.org/10.1038/ngeo102, 2008.

Schneider, D. P. and Steig, E. J.: Ice cores record significant 1940s Antarctic warmth related to tropical climate variability, P. Natl. Acad. Sci. USA, 105, 12154-12158, 2008.

Schneider, D. P., Deser, C., and Okumura, Y.: An assessment and interpretation of the observed warming of West Antarctica in the austral spring, Clim. Dynam., 38, 323-347, 2011.

Schneider, D. P., Okumura, Y., and Deser, C.: Observed Antarctic interannual climate variability and tropical linkages, J. Climate, 25, 4048-4066, 2012.

Schwanck, F., Simões, J. C., Handley, M., Mayewski, P. A., Bernardo, R. T., and Aquino, F. E.: Anomalously high arsenic concentration in a West Antarctic ice core and its relationship to copper mining in Chile, Atmos. Environ., 125, 257-264, 2016.

Shepherd, A., Ivins, E. R., Geruo, A., Barletta, V. R., Bentley, M. J., Bettadpur, S., Briggs, K. H., Bromwich, D. H., Forsberg, R., Galin, N., Horwath, M., Jacobs, S., Joughin, I., King, M. A., Lenaerts, J. T. M., Li, J., Ligtenberg, S. R. M., Luckman, A., Luthcke, S. B., McMillan, M., Meister, R., Milne, G., Mouginot, J., Muir, A., Nicolas, J. P., Paden, J., Payne, A. J., Pritchard, H., Rignot, E., Rott, H., Sørensen, L. S., Scambos, T. A., Scheuchl, B., Schrama, E. J. O., Smith, B., Sundal, A. V., van Angelen, J. 
H., van de Berg, W. J., van den Broeke, M. R., Vaughan, D. G., Velicogna, I., Wahr, J., Whitehouse, P. L., Wingham, D. J., Yi, D., Young, D., and Zwally, J.: A reconciled estimate of ice-sheet mass balance, Science, 338, 1183-1189, 2012.

Sigl, M., Fudge, T. J., Winstrup, M., Cole-Dai, J., Ferris, D., McConnell, J. R., Taylor, K. C., Welten, K. C., Woodruff, T. E., Adolphi, F., Bisiaux, M., Brook, E. J., Buizert, C., Caffee, M. W., Dunbar, N. W., Edwards, R., Geng, L., Iverson, N., Koffman, B., Layman, L., Maselli, O. J., McGwire, K., Muscheler, R., Nishiizumi, K., Pasteris, D. R., Rhodes, R. H., and Sowers, T. A.: The WAIS Divide deep ice core WD2014 chronology - Part 2: Annual-layer counting (0-31 ka BP), Clim. Past, 12, 769-786, https://doi.org/10.5194/cp-12-769-2016, 2016.

Simpkins, G. R., Ciasto, L. M., Thompson, D. W. J., and England, M. H.: Seasonal relationships between large-scale climate variability and Antarctic Sea Ice concentration, J. Climate, 25, 54515469, https://doi.org/10.1175/JCLI-D-11-00367.1, 2012.

Sinclair, K. E., Bertler, N. A. N., and Trompetter W. J.: Synoptic controls on precipitation pathways and snow delivery to high-accumulation ice core sites in the Ross Sea region, Antarctica, J. Geophys. Res., 115, D22112, https://doi.org/10.1029/2010JD014383, 2010.

Stammerjohn, S. E., Maksym, T., Masson, R. A., Lowry, K. E., Arrigo, K. R., Yuan, X., Raphael, M., Randall-Goodwin, E., Sherrell, R. M., and Yager, P. L.: Seasonal sea ice changes in the Amundsen Sea, Antarctica, over the period of 19792014, Elementa Science of the Anthropocene, 3, 000055 , https://doi.org/10.12952/journal.elementa.000055, 2015.

Steig, E. J., Schneider, D. P., Rutherford, S. D., Mann, M. E., Comiso, J. C., and Shindell, D. T.: Warming of the Antarctic icesheet surface since the 1957 International Geophysical Year, Nature, 457, 459-462, https://doi.org/10.1038/nature07669, 2009.

Steig, E. J., Ding, Q., Battisti, D. S., and Jenkins, A.: Tropical forcing of Circumpolar Deep Water Inflow and outlet glacier thinning in the Amundsen Sea Embayment, West Antarctica, Ann. Glaciol., 60, 19-28, https://doi.org/0.3189/2012AoG60A110, 2012.

Tao, G., Yamada, R., Fujikawa, Y., Kudo, A., Zheng, F., Fisher, D. A., and Koerner, R. A.: Determination of trace amounts of heavy metals in Arctic ice core samples using inductively coupled plasma mass spectrometry, Talanta, 55, 765-772, 2001.

Thomas, E. R., Hosking, J. S., Tuckwell, R. R., Warren, R. A., and Ludlow, E. C.: Twentieth century increase in snowfall in coastal West Antarctica, Geophys. Res. Lett., 42, 9387-9393, https://doi.org/10.1002/2015GL065750, 2015.

Tuohy, A., Bertler, N., Neff, P., Edwards, R., Emanuelsson, D., Beers, T., and Mayewski, P.: Transport and deposition of heavy metals in the Ross Sea Region, Antarctica, J. Geophys. Res.Atmos., 120, 10996-11011, 2015.
Turner, J., Phillips, T., Hosking, J. S., Marshall, G. J., and Orr, A.: The Amundsen Sea Low, Int. J. Climatol., 33, 1818-1829, 2013.

Turner, J., Hosking, J. S., Marshall, G. J., Phillips, T., and Bracegirdle, T. J.: Antarctic sea ice increase consistent with intrinsic variability of the Amundsen Sea Low, Clim. Dynam., 46, 23912402, https://doi.org/10.1007/s00382-015-2708-9, 2015a.

Turner, J., Hosking, J. S., Bracegirdle, T. J., Marshall, G. J., and Phillips, T.: Recent changes in Antarctic Sea Ice, Philos. T. Roy. Soc. A, 373, 20140163, https://doi.org/10.1098/rsta.2014.0163, 2015b.

Udisti, R., Bazzano, A., Becagli, S., Bolzacchini, E., Caiazzo, L., Cappelletti, D., Ferrero, L., Frosini, D., Giardi, F., Grotti, M., Lupi, A., Malandrino, M., Mazzola, M., Moroni, B., Severi, M., Traversi, R., Viola, A., and Vitale, V.: Sulfate source apportionment in the Ny-Ålesund (Svalbard Islands) Arctic aerosol, Rendiconti Lincei REND. Lincei-Sci, Fis., 27, Supplement 1, 85-94, https://doi.org/10.1007/s12210-016-0517-7, 2016.

Vallelonga, P., Barbante, C., Cozzi, G., Gaspari, V., Candelone, J.P., Van de Velde, K., Morgan, V. I., Rosman, K. J. R., Boutron, C. F., and Cescon, P.: Elemental indicators of natural and anthropogenic aerosol inputs to Law Dome, Antarctica, Ann. Glaciol., 39, 169-174, 2004.

Vance, T. R., Van Ommen, T. D., Curran, M. A. J., Plummer, C. T., and Moy, A. D.: A millennial proxy record of ENSO and Eastern Australian rainfall from the Law Dome ice core, East Antarctica, J. Climate, 26, 710-725, 2013.

Wagenbach, D., Ducroz, F., Mulvaney, R., Keck, L., Minikin, A., Legrand, M., Hall, J. S., and Wolff, E. W.: Sea-salt aerosol in coastal Antarctic regions, J. Geophys. Res., 103, 10961-10974, 1998.

Wedepohl, K. H.: The composition of the continental crust, Geochim. Cosmochim. Ac., 59, 1217-1232, 1995.

Weller, R., Woltjen, J., Piel, C., Resenberg, R., Wagenbach, D., Konig-Langlo, G., and Kriews, M.: Seasonal variability of crustal and marine trace elements in the aerosol at Neumayer station, Antarctica, Tellus B, 60, 742-752, 2008.

Weller, R., Wagenbach, D., Legrand, M., Elsässer, C., Tian-Kunze, X., and Konig-Langlo, G.: Continuous 25-yr aerosol records at coastal Antarctica - I: inter-annual variability of ionic compouds and links to climate indices, Tellus B, 63, 901-919, 2011.

Winton, V. H. L., Edwards, R., Delmonte, B., Ellis, A., Andersson, P. S., Bowie, A., Bertler, N. A. N., Neff, P., and Tuohy, A.: Multiple sources of soluble atmospheric iron to Antarctic waters, Global Biogeochem. Cy., 30, 421-437, 2016.

Zreda-Gostynska, G., Kyle, P. R., Finnegan, D., and Prestbo, K. M.: Volcanic gas emissions from Mount Erebus and their impact on the Antarctic environment, J. Geophys. Res., 102, 15039-15055, 1997. 